\title{
Profitability Analysis of Mergers and Acquisitions: An Event Study Approach
}

\author{
Mehroz Nida Dilshad (Corresponding author) \\ Cardiff Business School,Cardiff University \\ E-mail: nidadilshad@gmail.com
}

Received: December 2, 2012 Accepted: December 19, 2012

doi:10.5296/ber.v3i1.2781 URL: http://dx.doi.org/10.5296/ber.v3i1.2781

\begin{abstract}
The purpose of this research is to test the efficiency of market with respect to announcements of mergers and acquisitions using an event study methodology. Specifically, this study analyzed the effects of banks mergers and their announcements on the prices of stocks, in Europe. We study 18 deals that involve banks in Merger and Acquisition from year 2001 to 2010 in order to investigate the returns of shareholder of the targets and acquirers. Evidence here supports that significant cumulative abnormal returns were short lived for the acquirers. At the end of the event window, the cumulative abnormal returns were 0. Evidence of excess returns after the merger announcement was also observed along with the leakage of information that resulted in the rise of stock prices few days before the announcement of merger or acquisition. At the same time, the results of cumulative abnormal returns showed that target banks earned abnormal returns on the merger announcement day.
\end{abstract}

Keywords: Market efficiency, Mergers, Acquisitions, Shareholders, Banks, Information

\section{Profitability Analysis of Mergers and Acquisitions}

Mergers and acquisitions around the globe represent a huge reallocation of resources, within and across countries and therefore, it has been the interest of empirical studies for many years. There have been three merger waves in the 1960s with the multinational takeovers, in the 1980s there were aggressive takeovers and in the 1990s, there were global takeovers. Historically, the huge number of these merger and acquisitions were concentrated in the United States of America and United Kingdom. Extensive research has been done on whether acquisitions are profitable or lead to wealth reduction for shareholders and empirical studies have revealed that mergers tend to provide a mixed performance to the shareholders involved. 
Sherman et al. (2011) ${ }^{1}$ stated that mergers and acquisitions are one of the most effective ways to accelerate the implementation of a plan to grow rapidly. The impact of technology has increased the pace of the mergers and acquisitions.

When a merger or an acquisition is announced, a significant amount of information is revealed about that particular deal and this information can be used to evaluate the reaction of stock market to a merger or an acquisition announcement. Mergers and Acquisitions have created an intense competition for all the companies. In this era, acquisitions are increasing at a rapid pace and are being bid up at a higher rate. Banks have been undergoing a process of consolidation and restructuring. Factors such as globalization and competition have compelled banks to improve their effectiveness in providing financial services to meet the increasing demands for quality products and services. This leads to an appropriate assessment of banks performance reflecting their ability to survive the ongoing waves of activities such as mergers and acquisitions. Banks can increase their scale of operations to generate efficiency gains and as a result improve profitability. Consolidation process in the banking industry can be attributed to deregulation and technological changes that may facilitate banks to provide a large range of banking services in a larger geographical area. Basically the main aim of consolidation process in the banking industry is to increase gains through reduction of expenses, increased market power, and reduction in volatility of earnings. Bank mergers or acquisitions can increase the value by reduction in costs and increase in revenues. Cost reductions can be achieved by the elimination of unnecessary managerial positions and closure of overlapping branches of banks. Revenue can be increased by cross selling of services that banks offer.

Event study methodology has been applied to analyze the response of financial markets to changes in the banking industry as a result of Mergers and Acquisitions. Section 2 provides a series of literature review that concerns explanations for observed reactions of stock market with respect to acquisition announcement. Section 3 defines the background of Mergers and Acquisitions in Europe in the Banking industry. Section 4 outlines the selection methodology of data set with the following analysis of results revealed in the sample. Preliminary tests were also carried out to analyze the data set. Section 5 discusses the structure of an event study. Linear regression model was used as a predictor of abnormal returns and cumulative abnormal returns. It also states the limitations of this study. The results indicate positive and statistically significant gains in terms of value to the acquirers for a short term in the banking industry in Europe from the specified time period. The results also showed that share holders of target banks earned abnormal returns on the day of merger announcement. Section 6 presents the conclusion of the event study that has been carried out.

\section{Literature Review}

\subsection{Motives for Mergers and Acquisitions}

Mergers and acquisitions, also known as M\&A, involve the process of acquiring, selling, and combining of firms. The theories with respect to mergers and acquisitions can majorly be categorized into two groups of neoclassical theories and behavioral theories. Neoclassical

\footnotetext{
${ }^{1}$ Andrew J. Sherman, , Dickstein Shapiro Morin and Oshinsky (2011): Mergers and Acquisitions: An Introduction
} 
theory is based on the assumption that managers are rational and make rational choices to maximize the wealth for the shareholders whereas behavioral theory focuses on the assumption that managers are not rational and they do not represent the interests of the shareholders. These theories can be further categorized into external and internal motives. Internal factors, for instance, agency costs or synergy can be directly influenced by the management whereas the external motives such as globalization, or technology cannot be influenced by the management. Cost cutting, revenue enhancement and risk reduction are the possible factors that explain successful acquisitions with cost cutting being the most important factor for the banks worldwide. Mukherjreem et al. (2004) ${ }^{2}$ stated that primary motivation for Mergers and Acquisitions is to achieve operating synergies. Their results depicted that most of the firms believe that diversification is a justified motive for acquisitions as a means of reduction in losses when there are economic downturns.

According to Sharma (2009), economies of scale are one of the main arguments behind Mergers and Acquisitions. The implication is that banks get involved in M\&As to cut down the operating costs by reducing the branch networks and staff overheads and also by integration of information technology and risk management systems. Increased competition provides an incentive for banks to grow to take advantage of the large capital base and market power. Author further stated that geographical expansion might act as a defensive mechanism for banks planning to withstand external pressures arising from larger banks. Economies of scope are also one of the rationales behind Merger and Acquisition deals that involve banks. Sharma (2009) observed that such type of economies are exploited when bank merges its business with another financial firm in order to attain benefits from selling financial services from existing distribution networks. Banks also work on cross-border expansion to gain access to a large client base and also to diversify their income sources. Such type of expansion does not provide benefits from economies of scale because it does not include the overlapping of financial services. However, author stated that it might create cost efficiency as well as revenue efficiency by exploiting the information from the target to the acquirer. Deregulation is also one of the important factors for the increase in the number of mergers and acquisitions. Opportunities for firms are perceived as deals, which were initially prevented but they are made achievable through the process of deregulation.

\subsection{Neoclassical Theories}

One of the factors that fall under the neoclassical theories is the synergy factors which assume that managers will only be involved in Mergers and Acquisitions if the returns are positive for the target as well as the acquiring shareholders therefore creating a synergy with positively correlated gains for both groups of the shareholders ${ }^{3}$. Synergy factor exists if the two combined firms have a greater return than the two individual firms owing to reasons such as improvements in efficiency and increase in market power for the merged or acquired firms. One of the most frequently stated synergies with respect to Mergers and Acquisitions motives is the operating synergies in terms of economies of scope and economies of scale, for instance, ability to offer a wide range of products. Other kinds of synergies are financial synergies

\footnotetext{
2 Mukherjreem, T, K , Kiymaz, H and Baker, K. (2004). Merger Motives and Target Valuation: A Survey of Evidence.

${ }^{3}$ Berkovitch and Narayana (1993): Motives for takeovers: An empirical Investigation
} 
between firms that have an excess capital but with less expansion possibilities and the other one with the larger growth opportunities but with less capital and together they can attain higher profits. Agency cost is also one of the internal factors that are under the neoclassical theories. This is the cost that is incurred by the company when an agent is employed to make decisions for the welfare of the firm.

According to Harford (2005), Mergers and Acquisitions can be elucidated by technological and economic shocks to the economy ${ }^{4}$. If the environment of a firm changes, manager, who is assumed to exist under the neoclassical theory, has to react accordingly to these changes to improve the performance of the firm. For instance, if a new technology is introduced in the market to which a given firm does not have access, Merger or Acquisition between this company and the other one with this technologic expertise might create positive synergies.

\subsection{Behavioural Theories}

Behavioural theories can be categorized into agency motives and Hubris motives. In agency motives, managers are assumed to be rational but they do not represent the shareholder's interests and in Hubris motives managers are assumed to be non - rational. The problem arises under the agency motives because managers do not behave in a way that maximizes profits for the shareholders. As described by Jensen and Meckling (1976), the agency problems can arise due to managers that own a small amount of the shares of a firm and others owners do not own a larger enough share of the company to have an incentive to monitor the behaviours of the managers. In hubris motives, manager's non-rational behaviour or over confidence about the expected synergies resulting from mergers and acquisitions might lead to an overpayment of the target firms. As a result, the acquirers overpay for the target firms and realize negative profits whereas stockholder of the target banks witness value creation.

Therefore, because of these problems managers might behave in a manner to increase their own profits instead of those of the shareholders. For instance, to avoid the control loss that could deprive them of the private benefits, they might have to agree to a low premium offered in trade for a share in merged company. Resultantly, in this case it might result in the decrease of the profits of the shareholders. On the other hand, management might be more interested in paying out surplus cash flow to shareholders because it will decrease the control of resources of the management and they will not, therefore, engage in takeover activities which might not even maximize the profit for the shareholders. Another behavioural theory states that managers will expand the size of the firm by engaging in the activities such as Mergers and Acquisitions and therefore increase their personal compensation that might be attached to the firm size.

\subsection{Risks}

Several arguments surround the risk behind the Merger and Acquisition deals. There are also certain risks involved in the Merger and Acquisition deals. Sharma (2009) elaborated that operating risk is involved in these types of deal owing to the fact that it is difficult to incorporate technical systems, personnel culture as well as practices with respect to remuneration resulting in the loss of personnel and customers. Risks are more in cross border

\footnotetext{
${ }^{4}$ Harford (2005): What drives merger waves?
} 
deals in comparison to domestic deals. This is because cultural differences, foreign exchange risk, accounting regulations and perception of foreign clients in terms of deals add further difficulties. Lastly, other considerable factors of risks are the reputation risk which is a result of potential failure of the target bank causing the reputation of the acquirer bank to deteriorate and the strategic risk that is a source of misjudgment by the management of the acquirer bank with regard to the scope of the deal and the quality of the acquiring bank.

\section{Efficiency of Mergers}

\subsection{The Conventional Wisdom}

Caves (1987) observed that acquisitions always entail a large amount of gains for the shareholders of the target firm over the market value of the firm. Author stated that mergers tend to create value, are economically efficient and socially desirable. According to Agarwal (2007), it is difficult to assess the mode of success of a merger and whether it has been a success. Author further stated that estimates illustrated that about $80 \%$ of the mergers do not meet their financial targets, producing lower returns than it was expected and higher than the expected cost and about $50 \%$ of the mergers and acquisitions are failures. A crucial time period that determines the success or failure of a merger deal is the way in which the transition in the company is handled in the initial months. It also depends on the way employees of the target company assess the corporate culture of the acquirer and compare it with their culture. Furthermore, when firms are in the same line of business merged together, they have a better success rate in comparison to those companies that merge together in different sectors, the main reason being expertise, ease with which knowledge is transferred and economies of scale.

\subsection{Diversifying Mergers}

Caves (1987) explained that value of diversifying mergers lies in the managerial efficiency. Managerial efficiency and full use of resources and assets are the bases for the productivity of the mergers that are consistent with efficient capital markets and behavior that leads to wealth maximization. Mergers and Acquisitions might also result in financial efficiencies. For instance, firms may expand their earnings by acquiring other firms with dissimilar streams of earnings. Diversification in terms of earnings may decrease the variation in the profitability, leading to a reduction in the risk of bankruptcy. On the other hand, Caves (1987) stated that management of the acquirer might not succeed in maximizing the expected value, either because other motives dominate their preferences or it might be because an unrecognized bias inhibits their efforts. Event studies have found out that the market valuation of the target company declined for a time period prior to an acquisition. Therefore, negative abnormal returns could also be a result of disturbances such as financial crisis, faced by management that lower the expected profitability of the firm's resources, but in the ways that are remediable through consolidation with another company. According to Caves (1987), another explanation lies in the arbitrage, that is, acquisition is one way to acquire real assets when the share prices of the target firms are low.

\subsection{Tax Benefits}

Pautler (2003) explained that prior to the mid-1980s; there has been considerable reduction in 
tax benefits associated with mergers and acquisitions. However, the empirical evidence with regard to these benefits implied that they were not a major factor of motivation for the merger activity. Pautler (2003) further stated that the acquirer might preserve the net operating loss and other attributes of tax of the target firm, resulting in the tax liability reduction. If the acquiring firm and the target firm belong to the same line of business with applicability of different income tax rates, the acquirer might get the benefit from these differentials. In comparison to an asset acquisition, a merger does not create any issues of value added tax and business tax.

\section{Reasons of Failure}

Acquirers are generally of much larger size than the target firms and proportionally large size of the acquirer resulting from a merger of the target firm does necessarily indicate that it be a source of significant positive value to the acquirers. The main reason for the significant amount of failures lies in the attempt of the firms to merge their different identities into a single one. Agarwal (2007) observed that each merger differs from another, but they can be differentiated by some general rules that highlight the mistake of the companies and indicate the factors of success. When an acquirer plans to merge or acquire another company, the underlying idea is the corporate match and not a strategic objective. According to KPMG 2003, firms that merge mainly because of the corporate aims and not strategic objectives are more likely to face with the problem of conformity mismatch. Also, firms should focus more on cost reduction instead of focusing on development of the firm as a whole. Moreover, there lies a problem of inefficient communication. Efficient communication from the management provides an opportunity to retain key employees and also to attract the new employees.

According to Agarwal (2007), following are the reasons of the failures of merger and acquisitions:

\subsection{Flawed Strategy and Objective Clarity}

The strategic plans play a vital role in mergers. A business strategy is not enough to meet the expected plans and it might not be suitable for the target company. A good strategic analysis before a merger is important but it does not guarantee a success of a merger. The objective of the merger or an acquisition should be unambiguous and it should define that whether the acquisition or merger has a motive of value creation or it is increasing the shares in the market. KPMG (2005) survey found out that the respondents did not have a clear idea about the motive of the merger or acquisition and had different perceptions about it.

\subsection{Pre and Post Integration Planning}

Banks or firms are sometimes not able to keep their credibility up to the mark and have to face problems during the process of integration, especially from the different departments of the target firm. When the integration plan is made for the company; it is so rigorous that it does not take into account the ground realities when the process starts.

\subsection{Cultural differences}

The cultural difference between the firms is one of the main reasons for the resistance to 
management integration and communication in the workforce that further leads to uncertainty. This is generally observed in the cross border mergers and acquisitions. Cultural differences reflect the manner in which decisions are made between the firms. The acquiring companies do not stress more on the communication process and therefore, are not able to allay the anxieties of personnel of the target company. The slack attitude and lacking self motivation of the acquired company also plays a vital role in the failure of the merger. Such problem can act as an inhibitor at the time of increasing the value of stock holders.

\subsection{Lack of Experience and Knowledge}

Lack of experience and knowledge can lead to a poor audit before acquisition. Overpricing can also be one of the problems as sometimes the acquirer pays an excess premium to the target company. Lack of experience might lead to a loss of valuable time and thus synergies are lost.

\subsection{Over-optimism}

Agarwal (2007) stated that sometimes being over optimistic about the market conditions also results in the failure of merger deals. Management usually makes an attempt to discuss only the positive factors of the deals in order to win the votes of the shareholders to accept the overpriced deal.

\subsection{External Environment}

The external environment in the economy that surrounds the deal is quite complex and has to be scrutinized carefully before a merger or an acquisition. Different countries have their own criteria and it might be multifaceted. Most of the times the acquirer forgets to observe these factors and therefore, have to face difficulties while taking into account the regulations.

\section{Banking Industry}

Berger et al. (2004) ${ }^{5}$ studied the dynamics of market entry for the mergers and acquisitions. Their findings suggest that mergers and acquisitions are associated with the probability of entry into the markets of merger and acquisitions. Mergers and Acquisitions of the present firms should be incorporated in the future models of entry in industrial organization as well as banking research. The efforts should be put in evaluating different external effects of Mergers and Acquisitions on the behavior of the different market participants. The firms' responses with respect to prices, locations and product mix could be inclusive in the future industrial organization research. Authors suggested that the effects of Mergers and Acquisitions on deposit and interest rates, quantities of loans, distribution of deposits in different regions, and location of bank branches should be focused. Morris (2004) explained that the industry that has gone through fundamental transformations over the past 30 years is the banking industry. These transformations take into account both the changes in the social structure of the banks and the behavioural changes of the banks with respect to these changes. During this time period, banks had to compete with the competition around the globe and the financial crisis of the 1970s and 1980s. Resultantly, banks have undergone the process of Mergers and Acquisitions

\footnotetext{
${ }^{5}$ Berger,A. N, Bonime, S. D, Goldberg, L. G, and White, J. L. (2004, October): The Dynamics of Market Entry: The effects of Mergers and Acquisitions on Entry in Banking Industry.
} 
that has changed their corporate structure significantly and they are more focused on the assets in the industry. Over the past 30 years, banks have acquired other banks and they have also merged with other banks and also other financial intermediaries to save them from bankruptcy.

Focarelli et al. (2002) ${ }^{6}$ stated that the financial industry is being evaluated financially at an increasing pace in the current era. Firms have responded to the tough competition by reducing the costs and growing in size, increasing scale of operation, often by merging with opponents or by acquiring them. Inaccessible by protective regulations, banks are one of the most active players. Innovations with respect to technology and a systematic deregulation have provoked a wave of mergers in the banking industry around the globe, initiated in the United States and reaching Europe. The authors analyzed that a higher percentage of revenue is generated by services provided for mergers. In acquisitions, return on assets i.e. profitability of the buyer is affected positively. This could be owing to the fact that acquisitions are made by banks which have a strong position in the market and have a higher ratio of loans with respect to financial assets. This implies that banks' main point is lending. Lastly, they have a lower net balance from interbank market.

Focarelli et al. (2002) further elaborated that their results contradict those of Hadlock et al. $(1999)^{7}$ who concluded that return on assets is not a considerable predictor of acquisitions. By analyzing the mergers and acquisitions individually, results are found that are consistent with the hypothesis that increasing revenues resulting from the financial services is a strategic goal for mergers whereas enhancing the quality of the portfolio of loans of the bank is the main objective for acquisitions. A merger is required when selling of more services is involved. For mergers, the augmentation in non-interest income, counteracted by elevated labor costs in the initial years, a raise in the lending activity and a more well-organized utilization of capital boost up the profitability. For acquisitions, the increased profitability for the banks that are acquired is associated to the enhancement in the value of their loan portfolio.

Focarelli and Panetta (2003) observed that the unparalleled mergers analyzed in the current era are changing the corporate scenario. Consequences of short run mergers and long run mergers differ from each other. Authors stated that in the short run, mergers lead to an increase in the market power that is not favorable for the customers. In the long run, the rate on deposits of the banks involved in in-market mergers rise and mergers which do not change the market worth of shares of the bank have no affect on deposit rates in the short run. They further stated that deposit rates increase only when banks are successful in the cost reduction. In contrast, the changes in the rates are not because of the alteration in the quality of services.

According to Focarelli and Panetta (2003), there are a number of ways in which Mergers and Acquisitions can increase the effectiveness worldwide. First, the bigger firms that are a result of mergers and acquisitions might gain an access to technologies that are cost saving or stretch their fixed costs over a larger area thereby resulting in the overall cost reduction. The gains from efficiency can also be gained from the utilization of economies of scale: the contract might permit the merging firms to step into new markets and sell their products to a wider

\footnotetext{
${ }^{6}$ Focarelli, Panetta and Salleo (2002): Why do banks merge?

${ }^{7}$ Hadlock, Charles J., Joel E Houston, and Michael D. Ryngaert (1999): The Role of Managerial Incentives in Bank Acquisitions
} 
consumer base. Lastly, this also might enhance the managerial efficiency. On the other hand, the fact that the firms which are merged become more competent does not necessarily indicate that their efficiency gains are transferred to the customers through the reduction in price level. Mergers and acquisitions might increase the market power which leads to the increase in prices and decrease in the levels of activity. Focarelli and Panetta (2003) explained that effects of Mergers and Acquisitions on prices depends on many factors for instance, the ease with which the competitors enters the markets, geographical scale of the markets, etc.

\section{Cross-Border Mergers and Acquisitions}

Neary (2005) explained that cross-border mergers are an important fact in the world economy. They constitute most of the foreign direct investment. They also comprise of an increasing proportion of all the mergers. In addition, the author mentioned that other evidence suggests that cross border mergers coincide with market integration and trade liberalization. A research study by the European Commission stated that cross border mergers were leading form of adjustment by firms in Europe to the extension of single market in European Union. Neary (2005) explained that efficiency can be gained from number of sources, for instance cost savings through transferring technology internally, economies in the use of assets of firms or the combination of pricing and marketing decisions on differentiated products. Conversely, mergers may also increase costs, because different production structures and different corporate cultures have to blend in together. Author concluded that the model he used, predicts that trade liberalization encourages the waves of cross border mergers. Furthermore, another empirical prediction was the absence of extra cost charges; pattern of cross border mergers which is a result of integration of market is of comparative advantage, in a way that low cost firms tend to acquire high cost foreign rivals. As a result, model also predicts that cross border mergers and exports are both complements and not a substitute to each other. Lastly, the model shows that cross border mergers tend to decrease the factor demands and put less pressure on the returns to the productive factors.

According to Mody and Negishi (2001) cross border Mergers and Acquisitions in East Asian countries increased sharply from $\$ 3$ billion in 1996 to $\$ 22$ billion in 1999 and falling slightly to $\$ 18$ billion in 2000. These mergers and acquisitions involve more than 50 percent equity owned by foreign investors. In comparison to other East Asian countries, a significant number of cross border Mergers and Acquisitions deals involved investment in Malaysian firms prior to the East Asia's financial crisis in 1997. In Indonesia, Mergers and Acquisitions were traditionally limited but later between 1998 to 1999 they doubled to reach \$2.7 billion. Resultantly, cross border Mergers and Acquisitions have accounted for an increased share of foreign direct investment flows to East Asia. The share of foreign direct investment in East Asia rose from $6 \%$ to $13 \%$ from 1993 to 1997 and later, it increased further to $30 \%$ in $1999^{8}$.

\section{Stock Price Reaction: Theoretical Arguments}

According to Athanasoglou and Asimakopoulos (2009), the ultimate target for the management of the firm is to maximize the value of shareholders for companies having shares

\footnotetext{
${ }^{8}$ Source: Thomson Financial Securities Data
} 
listed on the stock exchange by reflecting it in their stock price. Authors further elaborated that any announcement of a merger or an acquisition deal between banks attracts the investors and shareholders of the bank as it gives them a chance to check the validity of the following two hypotheses:

"The information hypothesis": According to this hypothesis, the management team of the acquirer bank wants to proceed with the respective deal because they might be aware of the fact that the value of the target bank is underestimated.

"The inefficient management hypothesis": This hypothesis states that target bank is obligated to either make moves to improve the bank's operations in order to make it more efficient and therefore, prevent the merger or acquisition, or to allow the acquirer to acquire the bank.

Athanasoglou and Asimakopoulos (2009) further stated that, however, a deal does not necessarily always imply that the aim of the management is to maximize shareholder's wealth. If the utility function of the acquirer is increasing proportionately to the scale of the bank, it is possible acquirer bank will proceed with the deal to derive the benefits without taking into consideration the total cost involved which might be higher than the total worth of the target bank.

The announcement of a Merger or an Acquisition deal is expected to lead to one of the following changes:

\subsection{Shares of the Acquirer Bank:}

Athanasoglou and Asimakopoulos (2009) analyzed that there is a positive reaction in terms of share prices when a deal involves those banks that offer same services and are active in the same market. A negative reaction is observed when it is perceived that a deal serves only the personal interests of the acquirer management instead of the interests of the stockholders.

\subsection{Shares of the Target Bank:}

Authors further observed that a positive reaction is witnessed when investors feel that the share prices of the target bank are undervalued. The same can also happen in a case when management of the target bank is inefficient and therefore, the acquisition will result in attempts to improve the organizational structure of the bank as well as its operations which in turn would lead to improved performance.

\section{Empirical Evidence on Stock Performance on Announcement of Acquisition}

Jensen and Ruback (1983) stated that based on the empirical findings, the shareholders of target firms make significant profits whereas the profits of shareholders of the acquiring firms were almost zero. However the facts with regard to the return of the shareholder of acquiring firms were less consistent and more dependent of the span of the event window so that the abnormal return identified for acquiring firm shareholders increased if the event window is expanded. Another study by Moeller et al. $(2005)^{9}$ found that the aggregate abnormal return

\footnotetext{
9 Moeller,S. B, Schlingemann, F.P, and Stulz, R.M. (2005, April). Wealth Destruction on a Massive Scale? A study of Acquiring Firm Returns in the Recent Merger Wave.
} 
of the shareholders of acquiring firms had been $1.1 \%$ over that specific time period but owing to small number of takeovers that created unexpectedly large losses, the loss from 1991 to 2001 to the shareholders was approximately $\$ 216$ billion. Therefore, positive abnormal return cannot be inferred as the acquiring shareholders have not essentially gained from the acquisitions. Further analyzed by the authors, "acquiring firms shareholders lost 12 cents around acquisitions per dollar spent on acquisitions for a total loss of \$240 billion from 1998 to 2001 , they lost $\$ 7$ billion in all of the 1980's or 1.6 cents per dollar spent" (Moeller et al, 2005). The cumulative dollar loss from 1998 to 2001 of the shareholder of acquiring firm was large because of a small number of acquisitions with less synergy gains by firms which had high valuations. If these acquisitions did not happen, the wealth of the shareholders of the acquiring firms would have increased. According to Moeller, et al. (2005), firms that made these acquisitions with a significant amount of dollar losses did not perform well afterwards.

Mueller (1985) elaborated that over the last century, mergers have altered the corporate landscape. An examination of the 1000 biggest manufacturing companies of 1950 discovered that 384 companies had merged with other companies by 1973. Smiley (1976) and Mandelker (1974) stated that firms that were acquired had below average stock market performance preceding to their acquisition. These below average stock market returns may depict the decrease in market shares that is recorded following a company's acquisition. If this holds true and if the bad management precipitated the acquisitions, then the new management has not performed good as compared to the old management in improving the performance of the company as measured by comparing the market share to the similar but non acquired companies. Dewey (1961) explained that mergers occur to save the firms from bankruptcy. Firms that were acquired between 1950 and 1972 might have suffered greater loss in market shares had they not been acquired. Author's result implies that mergers cushion a company's fall; they do not modify its route. Mueller (1985) concluded that the relative loss in the market shares for acquired companies is very large that it is hard to believe that rates of returns on assets did not decline for the same companies as compared to the control group firms. Author found out mergers reduce the profitability of the merging companies.

Lambert et al. (1989) ${ }^{10}$ found that acquisitions which increase the total stock return are in larger number comparatively. In addition, from examining the stock return performance of the companies that are acquired on that date when the merger was announced and was approved, there was no indication that risk reducing mergers tend to occur at expense of the shareholder wealth. Bild et al. (2002) ${ }^{11}$ mentioned that there are several reasons why the reaction of stock markets at the time of merger announcement may not reflect whether the merger or an acquisition has a positive impact on fundamental estimation or not. A merger announcement is a source of information that is reflected in the stock price of the acquiring company. Information also includes the identity of the acquiring bank, the payment methods and information on the event itself. According to Bild et al. studies have shown that acquirer banks that use stock as the method payment experience lower returns as compare to those using cash as a means of payment. The explanation behind this empirical finding is that the acquirers offer

\footnotetext{
${ }^{10}$ Lambert, R. A, Lanen, W. N. and Larcker, D. F. (1989). Executive Stock Option Plans and Corporate Dividend Policy

${ }^{11}$ Bild, Guest, Cosh and Runsten (2002): Do takeovers create value? A residual income approach on UK Data
} 
stocks to other firms when they are overvalued in the stock market. Conversely, when a firm undertakes a new project with a positive NPV (net present value), the market value of the company will be affected, depending on whether the NPV meets the expectations. Expectations will be built into value if a firm is expected to get involved in projects with high positive NPV. Even if the new projects that are undertaken by firm have a positive NPV, there might still be a drop in value if the NPV does not meet the high expectation of the stock exchange.

Conclusively, shareholders may experience significant wealth effects in mergers and acquisitions. Mergers and acquisitions are essentially targeted towards improving profits and productivity of a firm. Simultaneously, the purpose is also to cut down the expenses of a firm. However, mergers and acquisitions are not all the time successful. Sometimes, the main objective for which the process has taken place loses focus. The success of mergers and acquisition is not dependent on only one factor; in fact it is determined by a number of factors. Studies have suggested that Mergers and Acquisitions might have some economic impact on the shareholders. In case of a purchase, the shareholders of the acquired company are benefited from the acquisition because the acquiring company pays a large amount for the acquisition. Conversely, the shareholders of the acquiring company might have to face some losses after the acquisition owing to the premium of the acquisition and the cumulative debt load.

\section{Context}

\subsection{Banking Mergers and Acquisitions in Europe}

White (1985) stated that one of the significant developments in the 1920s in the banking sector was the merger movement. Thousands of consolidations of banks created new giants and also helped in the speeding up other changes in the industry. Mergers facilitated commercial banks to expand more quickly into investment banking and helped in the reduction in the number of weak rural banks. Rockett (1998) explained that during 1970s and early 1980s, many banks and savings were formed for a number of reasons. In some of the cases, banks were viewed as a symbol of status and other opted banks for reasons such as to benefit their business. On the other hand, some invested in banks to receive returns on their investments. A sequence of developments in the mid 1980s caused rapid changes in the banking sector. In the late 1970s, all the Americans looked for ways to increase the earning of their savings because of the high inflation. Banks, because of regulation, were unable to act in response and mutual funds as well as brokerages started substituting banks as the guardians of their savings. Commercial banks survived these moments but the severe recession of late 1980s and early 1990s struck them. During this time period, weak banks required stronger institutions as their acquisition partners. Banks sought reasonable exit strategies through mergers. Therefore, this resulted in the commencement of merger trends that are still continued today.

Since the late 1990s, banks and other financial firms in Europe have been rushing into mergers and acquisitions in an attempt to compete in the increasingly global marketplace. It was United Kingdom that witnessed some significant Mergers and Acquisitions in European banking in the 1990s. Royal Bank of Scotland acquired National Westminster after it had to suffer from huge losses from options at stock market. Some of the other deals were acquisitions of Midland Bank by HSBC and of Abbey National by Santander. In France, Banque Nationale de Paris had 
to merge with Paribas; Credit Agricole acquired Credit Lyonnais and CIC, a privatized group of regional banks ${ }^{12}$. In the late 1997 and early 1998 Dutch banking group ING took over Belgium's Banque Bruxelles whereas Swiss Bank Corporation merged with Union Bank of Switzerland.

As far as Merger and Acquisition in European market was concerned, not all worked as it was planned. Bavarian Vereinsbank merged with Bayerrische Hypo Bank leading to the emergence of the new institution named as HypoVereinsbank (HVB). It later on became the Germany's second largest bank. The bank rapidly expanded in Poland and Austria, where it acquired Bank of Austria. But the merged bank had to face losses because of overstretching its financial services. Bad debts were also one of the major reasons of the losses, they witnessed. Different sorts of partnerships and alliances between European credit institutions were also not formed in a way as it was expected. In the year 1999, Commerzbank, which was Germany's fourth largest bank, negotiated for the creation of a pan-European investment bank that included Credit Lyonnais in France, BCI Intesa of Italy and Banco Santander Central SA in Spain. If this had happened as it was predicted, the mergers would have given a rise to cross border banking institution to take full benefit of the European single currency. But it did not happen, resulting in the failure of the investment banking plans and also there was no commercial banking alliance.

Ayadi and Pujal (2005) analyzed that the European banking sector has witnessed a rapid process of Mergers and Acquisitions during the 1990s. Deregulation, financial innovations, market power as well as market efficiency and the creation of Euro have fuelled the process of the mergers and acquisitions. Due to economic downturn, there was a break in Mergers and Acquisitions trend in the Europe in 2001 and 2002. Faced with risks, uncertainty and increased competition, banking sector adopted most of the economic strategies to decrease their costs and increase their revenues. Authors further observed that the argument that Mergers and Acquisitions increase the value of shareholders is based on the assumption that the predicted value of the firm as a result of merger or acquisition of two entities will increase in terms of creation of potential wealth and the sum of respective values of the two separate firms. Ayadi and Pujal (2005) carried out a statistical analysis on a sample of 151 Mergers and Acquisitions announced and completed by banks in the Europe from the period 1994 to 2000 to characterize the wave of Mergers and Acquisitions in Europe. The results showed that there was an acceleration of operations of Mergers and Acquisitions since 1996. It also showed that there was an emergence of 'mega banks' at national level since $1999^{13}$.

In 2006 and 2007, world experienced record number of Mergers and Acquisitions. Around the world, in the developed as well as in the developing countries, numerous deals took place. Most of these Mergers and Acquisitions led to an increase in number of private entities. This happened because many public organizations all around the world were either merged with the private institutions or they were acquired by giant private institutions. The reason behind this Merger and Acquisition trend was the emergence and rapid growth of Private Equity Funds, an

\footnotetext{
12 Case Studies of Big Bank Mergers in Europe

13 Ayadi and Pujal (2005): Banking Mergers and Acquisitions in the EU: Overview, Assessment and Prospects
} 
action of the private equity firms to seek capital from investors for their funds. Furthermore, the regulatory environment of the publicly owned companies and to attain growth of the short term earnings was also some of the reasons of this Mergers and Acquisitions trend. Mergers and Acquisitions that resulted in the privatization of the public undertakings took place in North America, Europe, China and Brazil ${ }^{14}$. One of the examples in North America is the acquisition of First Commercial Bank of Florida, Boca Raton by Bank of North America, Miami ${ }^{15}$. In China, the approval of this type of Mergers and Acquisition took place in 2006. In Europe, such type of Mergers and Acquisitions took place notably whereas the market for investment in private equities was strong in Europe.

According to Rockett (1998), one of the specific trends that have created a market of Mergers and Acquisitions is the expansion of financial services. The main aim of the banks is to expand in terms of their revenue sources and to get involved in the businesses that are less capital intensive. Acquisitions, like Nationsbank take-over by Montgomery Securities or purchase of Robertson Stevens by Bank of America, improved their income by diversifying into financial services products via acquisitions of investment banking companies. Furthermore, Rockett (1998) explained that banks are investing more in leasing companies and consumer finance companies to seek loans that can be further packaged and placed in the secondary market. From the perspective of a banker, these types of acquisitions have the advantage of adding to earnings while greatly leveraging the capital of institution that provides a greater return on equity.

As described by Rockett (1998), another factor that is prevalent in mergers is the mergers of banks of similar sizes with strategic visions. Factors behind these dealings are the social issues and they are identifiable owing to the fact that there is an absence of significant merger premium. Such type of dealings tends to create greater liquidity for the stock of the institutions that are merged and create more savings in terms of cost. An example of 'a merger of equals' is the merger of Banco de Oro with Equitable PCI Bank in 2006. Another trend in the bank mergers is the double-dip. The Author explained that concept of the double dip is the selection of the target of a merger partner based on the idea that acquiring firm will be acquired itself. In this case the target will initially get a premium for its sale to the acquirer and then an additional merger premium would be received when the acquirer is sold out. "An example of the double dip was California Bancshare (CBI), a holding company that had come into being through the acquisition of 11 independent banks" (Rockett, 1998).

Rockett (1998) further stated that market has recognized these trends of mergers and has rewarded banks in terms of their stocks accordingly. Some of the stocks were examined and viewed as good options because they added to their cash flows through successful mergers. The stocks, in the market, of the acquiring bank have been inflated. Consequently, it is less expensive for the acquirer to pay a higher premium for the target firm or bank with the help of the inflated currency. Rockett (1998) explained that at that time stocks of banks were being traded in the stock market at the highest multiples and stocks of the banking companies are trading at an average of 2.5 times their carrying value and 20 times their earnings.

${ }^{14}$ Mergers and Acquisitions trends

15 Thomson Financial Mergers and Acquisition Detailed Transaction Report 
Berger (2011) analysed that year 2006 was a start of frenzy in terms of Mergers and Acquisitions in stock and exchange markets. That same year, Chicago Mercantile Exchange acquired CBOT Holdings Inc. for 11.1 billion dollars and NYSE Group Inc. paid 10.2 billion dollars for Euronext $\mathrm{NV}^{16}$. New York Stock Exchange also acquired Archipelago Holdings for 2.26 billion dollars with the aim of getting into electronic trading. NASDAQ also bought 15\% stake in the London Stock Exchange. In year 2007, NASDAQ acquired Sweden's OMX AB for 4.1 billion dollars. Berger (2011) found out that OMX bought Dubai International Finance Centre for 3.4 billion dollars. NYMEX Holdings was acquired by CME Group Incorporation for 7.56 billion dollars and International Securities Exchange Holdings Incorporation was acquired by Eurex AG in a deal worth 2.8 billion dollars. In year 2008, BovespaHolding SA, that runs the Sao Paulo Stock Exchange, merged with BM\&F, Brazil's main derivative market, in a deal of 10.3 billion dollars.

Minney (2011) observed that currently London Stock Exchange is dealing with a 4.3 billion pounds merger with Canada's TMX exchange. The world is moving into fast consolidation of stock exchanges through mergers and acquisitions among the giant exchanges ${ }^{17}$. Author further stated that New York's NYSE Euronext is planning a 10 billion dollars merger with Deutsche Boerse in Germany that has probability of facing challenges on grounds of reducing competition. Furthermore, NASDAQ, US stock exchange is pondering over a rival bid for NYSE Euronext. NASDAQ is valued at 5.7 billion dollars and it might become a takeover target for the other stock exchanges if it does not grow. Minney (2011) further mentioned that the Singaporean Stock Exchange plans to merge with the Australian Stock Exchange as a growing share of trading in the world and rise-in-capital moves to Far Eastern and Chinese markets. A few years ago JSE Ltd stock exchange of South Africa wanted to acquire a stake in the Stock Exchange of Mauritius but this was not allowed by regulators. Conventionally, African leaders and regulators see them as national institutions and prefer sovereignty to liquidity and efficient capital markets.

\section{Case Studies}

\subsection{Barclays Acquired Lehman Brothers}

Lehman Brothers Holdings was established in the year 1850. The company was one of the leaders in global finance. The activities of the company mainly revolved around the underwriting of debt and equity, advice on mergers and acquisition and banking activities that included equity and debt research, mortgage banking, lending of securities, etc. DePamphilis (2009) stated that the credit crisis of 2008 forced Lehman Brothers to seek protection from its creditors. Lehman Brothers had planned to restructure their operations, improve their performance and reduce the overall cost structure. Top executives proposed to sell a majority of the firm's investment management business and the firm had also explored the deal of its broker dealer operations, that is, a business of trading of securities and broker network. Conversely, with the loss of confidence in the capital markets and Lehman Brothers, the firm was not left with many options. Lehman Brothers Holdings, Inc. (LBHI), a holding company,

\footnotetext{
${ }_{16}^{16}$ Berger (2011): Famous Stock and Securities Market Mergers and Acquisitions

17 Minney (2011): Stock exchanges merger trend will end with "three, four" global exchanges
} 
on September 15, 2008, announced that it had filed a petition under Chapter 11 of the U.S. bankruptcy code ${ }^{18}$.

As reported by DePamphilis (2009), with assets worth 639 billion dollars and the liabilities worth 613 billion dollars, Lehman Brothers is the largest bankruptcy in the history in terms of the assets. On $20^{\text {th }}$ September, 2008 Barclays PLC which is one of the major banks in United Kingdom, acquired Lehman Brothers' Investment Banking in North America and paid 250 million dollars for the broker dealer operations. Barclays also paid a further 1.5 billion dollars for the New York headquarters building of the firm and two data centres based in New Jersey. Barclays did not buy any of the real estate assets and hedge fund investments of Lehman Brothers. However, Barclays agreed to invest 47.4 billion dollars in the securities of Lehman Brothers. The acquisition combined two franchises and product offerings of two clients creating a significant value for Barclays' shareholders. The Lehman Brothers businesses were highly complementary fit for the investment banking business of Barclays. The combination of the two businesses confirmed Barclays' Capital as a leading debt capital markets house worldwide. It also gave them an opportunity to extend Barclays' Capital's range of investment banking products inclusive of Lehman Brothers strong US Mergers and Acquisitions and equity capital markets franchises. The acquisition resulted in the proportion of the revenues of Barclays derived from the US rising significantly.

\subsection{Carnegie Bank Took over HQ Bank}

Koch (2009) stated that Carnegie Bank was founded in 1803 and is one of the leading independent investment banks in Sweden. It has officess in Stockholm, London, New York, Luxembourg as well as in Geneva. On 3rd September, 2010 HQ Bank was absorbed into Carengie Investment bank. HQ bank was a Swedish finance and banking corporation. As reported by the Author, income of the Carnegie Investment Bank was approximately SEK ${ }^{19}$ 1,161 million. There was an increase in all business areas in comparison to year 2010. Pre-tax profit was approximately SEK 603 million whereas the capital ratio amounted to $20.1 \%$ by the end of year 2010. The acquisition of the HQ Bank took place when it was undergoing the process of liquidation and was closed during the week prior to the acquisition. According to the Koch (2009), the uncertainty that prevailed before the acquisition resulted in a number of customers of the HQ Bank requesting to transfer their accounts of deposits. When Carnegie Investment Bank took over, all obligations to the customers of HQ Bank were assured. President of the Carnegie Holding, Lindelow, stated that the first phase of the integration turned out to be successful. The new acquisition has assets under management totaling more than SEK 110 billion. The original Carnegie Bank also continued to show an upward i.e. positive trend in their profits.

\subsection{Sovereign Bank Acquired by Banco Santander}

Banco Santander is a financial services group in Spain. It acquired Sovereign Bancorp Incorporation; company of Sovereign Bank situated in United States, on $30^{\text {th }}$ January, 2009. According to McGlasson (2008), Banco Santander is one of the most profitable banks in

18 DePhamphilis (2009): Case Study: Lehman Brothers files for Chapter 11
${ }_{19}$ Swedish currency 
Europe. The Spanish bank had previously bought a 25 percent share of the Sovereign Bankcorp that was based in Wypmissing, PA. and their operations are widely spread across the Northeast. The acquisition improved the geographical diversification of the company. Banco Santander predicted that Sovereign will have total profit of 750 million dollars by the end of 2011 . McGlasson reported that Banco Santander has assets worth EUR 918,332 million and managed funds worth 1,050,928 million Euros. It is one of the largest financial groups in Spain and Latin America. Espinoza (2008) stated that after the announcement of the acquisition, shares of the Banco Santander had risen by $12.4 \%$ that closed at 10.19 Euros i.e. 13.84 dollars in Madrid, as reports came out of the bids of the banks. On the other hand, shares of Sovereign Bancorp fell by $3.4 \%$ (13 cents) to close at 3.68 dollars. Furthermore, "Santander's American depositary receipts were up $11.3 \%$, or $\$ 1.47$, to close at $\$ 14.50$ in New York" (Espinoza, 2008). Blumenthal (2008) reported that initially Santander, Spain’s largest bank, owned 24.35 percent of the Sovereign Bankcorp and later it bought the remaining 75.65 percent for $\$ 3.81$ dollar per share which was reported to be a closing price of the acquired bank. The Spanish bank took into account that Sovereign Bankcorp was acquired according to the book value and expects it to show an upward trend in earnings per share by the year 2011.

\subsection{Lloyds TSB Acquired HBOS}

Lloyds TSB, a British bank, announced on $18^{\text {th }}$ September, 2008 the take over of Halifax Bank of Scotland in an agreement worth $\mathrm{GBP}^{20} 12.2$ billion. HBOS which is banking and an insurance company was taken over in year 2009 by the Lloyds TSB. Share of HBOS went down by 19.2 percent (147.1 pence) at the close of trading on 17th September, 2008 after the collapse of Lehman Brother, US investment bank, and shock after shock faced by the financial markets. MacAskill and Menon (2009) stated that approximately 83 percent of the insured assets were acquired when Lloyds TSB bought HBOs. This acquisition resulted in one of the largest financial institutions in the banking industry. According to Peston (2008), the reason behind the facilitation of takeover by government was that the depositors and lenders of HBOS were withdrawing their deposits from HBOS after all the downward pressure on HBOS's share prices. The government had to step in to prevent further turmoil in the financial system as it was evident that HBOS was in a difficult position. While the size of the new acquisition triggered worries in terms of competition, the government supported the deal since it would help in the maintenance of the stability of the banking sector. Resultantly, Goldman Sachs cut out HBOS from its buying list of European banks. Author further stated that after the acquisition, Lloyds banking Group faced a loss of 4 billion pounds in the first six months after the acquisition and after they wrote down the value of assets of HBOS. The assets were even worth less than it was initially thought. Lloyds is the one of the biggest retail banks in the United Kingdom and now $43 \%$ of its share is of the taxpayer, after it announced a loss of 13.4 billion pounds, primarily because of the bad debts following an acquisition of HBOS.

\section{Data}

\subsection{Data Sources}

${ }^{20}$ Currency: Pound Sterling 
All the deals of Mergers and Acquisitions have been gathered from database Thomson One Banker. The total number of available merger deals in Europe is 1020. Of these, 18 deals were chosen between year 2001 and 2010 to narrow down the sample size. The research focuses on the firms acquiring other firms in Europe only. The second criterion taken into consideration is that only those Mergers and Acquisitions that have been completed and the firms have acquired a final stake of $100 \%$ in the target company. The third criterion set is that there has to be 30 days or more between announcement date and effective date, the date on which merger took place, for the respective Merger or Acquisition. For the acquirer companies as well as for the target companies, share prices were collected for 120 days for the estimation of parameters. The fourth criterion set is that only Mergers or Acquisitions in the banking sector are included. Furthermore, banks that are included in the sample were not engaged in more than one deal during the year in order to segregate the information content of specific deals. It also restricts the sample requiring both the acquirer and the target bank to have their shares listed on the stock exchange. As for share prices of the companies, the criteria followed was taking the availability of daily prices into account. Daily share prices were extracted from Data Stream.

The reason behind the extraction of data with respect to the announcement date and not the effective date is owing to the underlying assumption of efficient markets that states that the stock prices change immediately after the announcement of a Merger or an Acquisition. Deals that have only announcement dates but are still pending are excluded from the dataset. Firms that have rumor dates apart from the announcement dates are also excluded from the data set because the potential shift in prices already would have happened at the rumor date as the hypothesis states that any information will be absorbed in the prices instantly after the deal has been announced. The rumor date would create biasness in the estimation of the abnormal returns because the potential shift in prices will then lie in the period of estimation instead of on the event day. Resultantly, any considerable effect from the event would be diluted.

\subsection{Weaknesses of the Data}

In order to test the hypothesis that the CAR (cumulative abnormal return) for the firm's securities is 0 , it is necessary to collect daily returns on the securities of the target and acquiring banks over specific time period. The problem with finding the data was that the stock prices of target banks or acquirer banks were not always readily available. Thus only those banks were incorporated in the data set whose security prices around one year of the announcement of merger are available. Moreover, Sharma (2009) suggested that ideal model would incorporate daily returns of a value weighted bank security index, index whose securities are weighted in accordance with the total market value of their outstanding shares, for the determination of abnormal return of the merging bank's stocks over and above that of the value weighted index of stocks of banks.

In order to take macroeconomic changes into account, historical daily returns of the FTSE100 were incorporated. Based on the assumption that markets are semi-strong efficient and they incorporate all the information that is publicly known, any changes with respect to macro economy will be included in the closing values of FTSE100. The variables like abnormal returns would incorporate the announcement dates of mergers individually for every 
acquisition in the data set so as to determine the various window dates for the acquiring banks. However, determination of event windows that accurately captures the effect of announcement depends on how quickly researchers think information leaks out. Another drawback is that the dividend payments are not taken into account during these 120 days for the estimation of value creation for shareholders.

\subsection{Data Sample}

In Table 1 the overview of key information of the selected mergers in the sample has been given. The sample covers European countries such as Germany, Spain, Denmark, Italy, Greece and United Kingdom. From the data set, it can be seen that mergers vary in sizes from small ones like Landesbank Berlin, Max Bank to big ones like Lloyd TSB Group PLC, Santander Hispano etc.

Table 1. European Bank Mergers \& Acquisition in the Sample

\begin{tabular}{|l|l|l|r|}
\hline Date $^{21}$ & Target Name & Acquiror Name & Ranking Value $^{22}$ \\
\hline $10 / 01 / 2010$ & Berlin-Hannoversche & Landesbank Berlin AG & 8.77 \\
\hline $06 / 25 / 2010$ & Banco Guipuzcoano SA & Banco de Sabadell SA & 419.22 \\
\hline $05 / 27 / 2010$ & Skaelskor Bank A/S & Max Bank A/S & 6.14 \\
\hline $11 / 02 / 2010$ & Turkiye Garanti Bankasi AS & BBVA & $3,831.53$ \\
\hline $10 / 26 / 2009$ & Standard Life Bank PLC & Barclays Bank PLC & 368.67 \\
\hline $09 / 25 / 2008$ & Banco de Credito Balear SA & Banco Popular Espanol SA & 144.98 \\
\hline $09 / 17 / 2008$ & HBOS PLC & Lloyds TSB Group PLC & $25,439.45$ \\
\hline $07 / 14 / 2008$ & Alliance \& Leicester PLC & Banco Santander SA & $2,517.95$ \\
\hline $09 / 12 / 2008$ & Deutsche Postbank AG & Deutsche Bank AG & $1,578.57$ \\
\hline $04 / 03 / 2006$ & Finansbank AS & National Bank of Greece SA & $2,258.16$ \\
\hline $05 / 24 / 2004$ & WestfalenBank AG & Bayerische Hypo- und Vereins & 138.01 \\
\hline $07 / 23 / 2004$ & Abbey National PLC & Santander Central Hispano SA & $15,787.49$ \\
\hline $12 / 14 / 2004$ & Northern Bank Ltd & Danske Bank A/S & $1,863.51$ \\
\hline $02 / 17 / 2003$ & Interbanca SpA & Banca Antonveneta SpA & 384.55 \\
\hline $02 / 05 / 2003$ & Entrium Direct Bankers AG & DiBa & 323.61 \\
\hline $12 / 19 / 2003$ & Banco Atlantico SA & Banco de Sabadell SA & $1,840.57$ \\
\hline $04 / 14 / 2003$ & Wuerttembergische Hypotheken & Bayerische Hypo- und Vereins & - \\
\hline $10 / 30 / 2001$ & Rheinische Hypothekenbank & Deutsche Hypothekenbank & $1,831.94$ \\
\hline
\end{tabular}

Graphs (Appendix 2) show the variations in the share prices of all the acquirers and target banks 30 days before and after the announcement period. In some of the graphs, for instance, National Bank of Greece (Graph 9), Finansbank (Graph 27) etc the stability in the share prices can be observed. In other graphs, like Santander Central Hispano (Graph 10), Danske Bank (Graph 11) etc, continuous fluctuations can be seen in the stock prices with a significant fall in share prices after the announcement date. Some of the banks like Deutsche Postbank (Graph 26), Rheinische Hypothekenbank (Graph 34) have performed badly after the merger announcement whereas banks like Bayerische Hypo- und Vereins (Graph 17), Northern Bank (Graph 29) performed well after the merger announcement. Banks like Banco Guipuzcoano (Graph 19), HBOS (Graph 24) witnessed significant fall in share prices throughout the period. However, graphs of banks such as Banco Atlantico (Graph 32), Bayerische Hypo- und Vereins

21 Announcement Date

22 Value of Target banks (\$Mil) 


\section{Macrothink}

Business and Economic Research ISSN 2162-4860 2013, Vol. 3, No. 1

(Graph 15) etc depict the constant increase in the stock prices during the specified time period $(-30,+30)$. On the contrary, share prices of banks like Alliance \& Leicester, Landesbank Berlin were volatile.

Table 2.

\begin{tabular}{|l|r|r|}
\hline Acquirer Banks & Days -30 & Days +30 \\
\hline Banco de Sabadell SA & 3.493033 & 4.146967 \\
\hline Max Bank A/S & 46.26567 & 48.21267 \\
\hline BBVA & 9.285417 & 7.87028 \\
\hline Barclays Bank PLC & 369.455 & 316.6383 \\
\hline Banco Popular Espanol & 6.921583 & 7.074703 \\
\hline Lloyds TSB Group PLC & 149.2137 & 104.664 \\
\hline Banco Santander SA & 10.80554 & 10.66146 \\
\hline Deutsche Bank AG & 54.0983 & 40.38897 \\
\hline National Bank of Greece & 28.381 & 27.82433 \\
\hline Santander Central Hisp & 7.738947 & 7.101963 \\
\hline Danske Bank A/S & 156.7953 & 154.1967 \\
\hline Banca Antonveneta SpA & 12.92033 & 14.68767 \\
\hline DiBa & 114.8777 & 121.415 \\
\hline Banco de Sabadell SA & 3.968927 & 3.9883 \\
\hline Bayerische Hypo- und & 432.9677 & 618.038 \\
\hline Deutsche & 26.05933 & 27.54233 \\
\hline Bayerische Hypo- und & 111.6 & 106.325 \\
\hline Landesbank Berlin AG & 3.389733 & 3.327933 \\
\hline
\end{tabular}

Table 3.

\begin{tabular}{|l|r|r|}
\hline Target Banks & Days -30 & Days +30 \\
\hline Banco Guipuzcoano & 5.24 & 4.827 \\
\hline Skaelskor Bank & 22.45333 & 12.6 \\
\hline Turkiye Garanti Bankasi & 8.675667 & 8.686 \\
\hline Standard Life Bank & 217.1 & 216.35 \\
\hline Banco de Credito Balear & 12.476 & 16.29667 \\
\hline HBOS & 288.2907 & 124.192 \\
\hline Alliance \& Leicester & 311.9667 & 336.3333 \\
\hline Deutsche Postbank AG & 43.482 & 28.68867 \\
\hline Finansbank AS & 3.110333 & 2.966333 \\
\hline Abbey National PLC & 487.9583 & 583.65 \\
\hline Northern Bank Ltd & 738.25 & 785.3667 \\
\hline Interbanca SpA & 20.378 & 20.54867 \\
\hline Entrium Direct Bankers & 11.00367 & 11.62 \\
\hline Banco Atlantico & 64.265 & 71.17333 \\
\hline Wuerttembergische & 113.15 & 113.2883 \\
\hline
\end{tabular}




\begin{tabular}{|l|r|r|} 
Rheinische & 610.163 & 590.3007 \\
\hline WestfalenBank & 15.00767 & 14.007 \\
\hline Berlin-Hannoversche & 7.154333 & 6.748667 \\
\hline
\end{tabular}

Table 2 gives an overview of the mean values of prices for the acquirers 30 days before $(-30,-1)$ and after $(+1,+30)$ the announcement of the merger. It can be seen from table 2 that average share prices of banks such as Banco de Sabadell, Max Bank, DiBa, have increased after the merger announcement whereas average stock prices of banks like Barclays, Lloyds TSB Group, Santander Central Hispano, etc have decreased, implying that they did not perform well after the announcement of acquisitions.

It can be seen from Table 3 that average value of the stock of target banks such as, Banco de Credito Balear, Alliance \& Leicester, Abbey National PLC, etc have increased indicating a good performance post merger announcement. No significant difference in share prices has been observed in the banks, such as Turkiye Garanti Bankasi, Interbanca, Entrium Direct Bankers etc before and after merger announcement. Conversely, Skaelskor Bank, Standard Life Bank, HBOS, etc observed a decrease in their average value of stock prices after the merger announcement.

Table 4.

\begin{tabular}{|l|r|l|l|r|}
\hline Acquirer Banks & \multicolumn{1}{|l|}{ Avg. } & Std. dev & \multicolumn{1}{l|}{ Min } & \multicolumn{1}{l|}{ Max } \\
\hline Banco de Sabadell SA & 0.002152 & 0.021494 & -0.04474 & 0.091667 \\
\hline Max Bank A/S & $-8.2 \mathrm{E}-06$ & 0.027898 & -0.06065 & 0.133195 \\
\hline BBVA & 0.00018 & 0.020848 & -0.04586 & 0.072912 \\
\hline Barclays Bank PLC & 0.001288 & 0.024755 & -0.07967 & 0.066986 \\
\hline Banco Popular Espanol SA & -0.00273 & 0.041053 & -0.09573 & 0.159999 \\
\hline Lloyds TSB Group PLC & -0.00548 & 0.053342 & -0.15103 & 0.203106 \\
\hline Banco Santander SA & 0.000234 & 0.018409 & -0.04304 & 0.055266 \\
\hline Deutsche Bank AG & -0.00684 & 0.041211 & -0.16532 & 0.13705 \\
\hline National Bank of Greece SA & 0.000703 & 0.015368 & -0.03696 & 0.037716 \\
\hline Santander Central Hispano SA & -0.0003 & 0.012461 & -0.04077 & 0.035711 \\
\hline Danske Bank A/S & 0.001261 & 0.009238 & -0.05753 & 0.025784 \\
\hline Banca Antonveneta SpA & 0.000485 & 0.021676 & -0.05243 & 0.0571 \\
\hline DiBa & 0.001909 & 0.006777 & -0.01227 & 0.038961 \\
\hline Banco de Sabadell SA & 0.001873 & 0.007857 & -0.02261 & 0.029416 \\
\hline Bayerische Hypo- und Vereins & -0.00066 & 0.041817 & -0.11757 & 0.112042 \\
\hline Deutsche Hypothekenbank & 0.00135 & 0.018324 & -0.03676 & 0.162297 \\
\hline Bayerische Hypo- und Vereins & 0.000163 & 0.006312 & -0.0625 & 0.009524 \\
\hline Landesbank Berlin AG & 0.000342 & 0.014012 & -0.05042 & 0.053097 \\
\hline
\end{tabular}

In the event study, equity returns are analyzed rather than the share prices. Therefore, Table 4 provides the summary of properties of returns for the acquirers. Some of the banks experienced average increase in share prices and on the other hand, some observed an average decrease in stock prices in the sample period. For instance, it can be seen that, in the case of Banco de Sadabell SA, on average per day share price increased by $0.2 \%$ which corresponds approximately to $75.32 \% 23$ increase in one year. Comparatively, share price of Santander

\footnotetext{
23 Average Share Price $* 350$ days; $0.002152 * 350=75.32 \%$
} 
Central Hispano SA decreased by $10.5 \%$ in one year. From the table we can see, the maximum loss in the share prices was witnessed by Deutsche Bank i.e. 16.5\%. The maximum daily return in the equity prices in acquirers can be observed in the case of Deutsche Hypothekenbank i.e. $16.23 \%$. Standard deviation depicts how much dispersion there is, in the data set, around the mean value. The highest standard deviation is of Lloyds TSB Group i.e. 0.053342 depicting the maximum deviation from its mean. In other words, we can say that the equities of Lloyds Bank were the riskiest.

Table 5.

\begin{tabular}{|l|r|r|l|r|}
\hline Target Banks & \multicolumn{1}{|l|}{ Avg. } & \multicolumn{1}{l|}{ Std. dev } & \multicolumn{1}{l|}{ Min } & \multicolumn{1}{l|}{ Max } \\
\hline Banco Guipuzcoano & -0.0012 & 0.011157 & -0.04082 & 0.030369 \\
\hline Skaelskor Bank & -0.0083 & 0.046616 & -0.20476 & 0.184466 \\
\hline Turkiye Garanti Bankasi & 0.002019 & 0.020592 & -0.04878 & 0.05814 \\
\hline Standard Life Bank & 0.001598 & 0.017284 & -0.04675 & 0.054335 \\
\hline Banco de Credito Balear & -0.00046 & 0.041644 & -0.09965 & 0.289438 \\
\hline HBOS & -0.00824 & 0.102567 & -0.41542 & 0.311966 \\
\hline Alliance \& Leicester & -0.00238 & 0.062221 & -0.13581 & 0.527936 \\
\hline Deutsche Postbank AG & -0.00845 & 0.041928 & -0.23792 & 0.105356 \\
\hline Finansbank AS & 0.002649 & 0.031 & -0.12991 & 0.09901 \\
\hline Abbey National PLC & 0.002822 & 0.021456 & -0.03966 & 0.176471 \\
\hline Northern Bank Ltd & 0.001145 & 0.00966 & -0.02759 & 0.035211 \\
\hline Interbanca SpA & 0.002895 & 0.014029 & -0.01948 & 0.134529 \\
\hline Entrium Direct Bankers AG & -0.00171 & 0.054606 & -0.34483 & 0.162791 \\
\hline Banco Atlantico & 0.00268 & 0.021014 & -0.08571 & 0.101905 \\
\hline Wuerttembergische Hypotheken & 0.00023 & 0.002036 & -0.01111 & 0.006732 \\
\hline Rheinische Hypothekenbank & -0.00048 & 0.005103 & -0.01015 & 0.016364 \\
\hline WestfalenBank & -0.00324 & 0.020145 & -0.09441 & 0.05977 \\
\hline Berlin-Hannoversche & 0.001074 & 0.028934 & -0.20128 & 0.142123 \\
\hline
\end{tabular}

In Table 5 properties of returns of target banks are summarized. Share prices of target bank like Standard Life Bank jumped by 55.93\% in one year. On the contrary, bank such as Banco Guipuzcoano experienced a decrease in share prices by $42 \%$ in one year. The maximum daily return in the stock prices was observed by Alliance \& Leicester Bank with $52.779 \%$ and HBOS faced the maximum loss on their equity prices i.e. $41.542 \%$. The most volatile returns were on the equities of Wuerttembergische Hypotheken Bank with the amount $0.2036 \%$.

Table 6 gives an overview of R-squared value of target companies as well as acquirer companies. It was calculated by regressing returns on shares of each of the banks on the market index. R-squared value shows how closely returns of individual stocks are related with the market index. A low R-squared value of banks, for instance, Max Bank, Skaelskor Bank, Entrium Direct Bankers, etc shows that there is no significant relation between the portfolios i.e. returns on shares prices and the market index. On the other hand, a significant relationship can be observed in the case of Banco de Sabadell between share prices and the market index since the value is closer to 1 i.e. 0.60278163 . 


\section{Methodology and Empirical Results}

\subsection{The Event Study Approach}

The analysis that is conducted on the data set is an event study with a relatively standard methodology. The event study methodology is used to examine the returns that are derived from the stock prices of the firms before the announcement as well as after the announcement of a merger and acquisition. The abnormal return depicts the part of the return that is not predicted by the market index and is, therefore, an estimate of the difference in firm's value due to the event. The predicted return is the return that is expected if no merger announcement event took place. The firm's beta, that represents the sensitivity of the stock returns with respect to the market index, is measured over an estimation period of 60 days prior to event window and the abnormal return is measured over a period of 30 days before and after the announcement date (event window of 61 days and announcement date is designated as day 0 in event window) following Brown \& Warner (1985).

\subsubsection{Day 0}

According to Halpern (1983), the announcement date is the most appropriate date to gauge the impact of an event. If information leaks before this date, abnormal returns that are generated by the merger would be observed before the event date. Halpern (1983) further stated that at the date of announcement, the stock prices of the acquirer firm will adjust accordingly to reflect the probability of the success of the deal, the profitability of the merger and the time period required to conclude the merger. The event study methodology has been found to be consistent and accurate when quantifying any corporate event. Day 0 depicts the first trading day when the news of acquisition or merger reaches the market. Accurate information of this day is important in order to observe the reaction of stock market to unexpected information. In this case, the date of announcement has been set after the effective information is released and the market would have accommodated the shock. Deals in the data set that are examined in this study records the announcement date.

\subsubsection{Estimation Window}

A few days around the date of announcement are included in the estimation and the event window because it is not sure that the day 0 was chosen correctly. Estimation window is used to obtain the parameters of the market model in order to calculate expected return on equities when there was a merger announcement and when there was not a merger announcement.

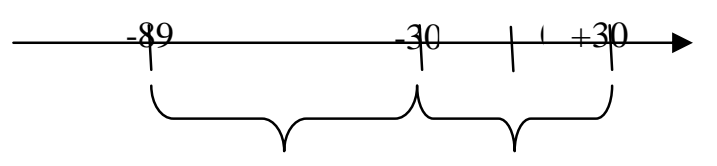

Estimation window $\quad$ Event window

In order words, pre-event time period i.e. from -89 to -31 is an estimation window. MacKinlay (1997) suggested that in this way, one can take information leakage, slow market reaction and effects of end of trading days into account. 


\subsubsection{Event Window}

The event window shows the number of days over which we are supposed to measure the possible abnormal returns that are caused by the event i.e. merger or an acquisition. The theory of the efficient market hypothesis stated earlier suggests that any change in the security prices caused by the event will be observed immediately owing to the rational behaviour that talks in the favour of short event window. The long window could result in the risk that might dilute the possibility of finding any considerable empirical evidence. On the other hand, if the event is too short, there might be a possibility that we do not observe the effect of the event if the information is available after the closing of the market and therefore, it fails to reach the public until the next working day or if the information is leaked out the day before the date of announcement and therefore, it can cause the effect on the day before the event day. To make sure that these possibilities are taken into account, the event window is set to 61 days that contains the announcement date, 30 days prior to it and 30 days after it.

\subsection{Structure of an Event Study}

Halpern (1983) stated that a merger or an acquisition might alter the underlying risk of the acquirer's assets and this affects the systematic risk of the shareholders of firms. An analysis of regression was performed in order to compare the actual daily return for each firm to the daily return of the market. The return on the shares of firms represents the dependent variable and the FTSE100 return is the independent variable in the equation. The regression covered the preevent time period i.e. from Day -89 to Day -31, to find the value of alpha and beta. Alpha denotes the value of intercept and beta represents the slope coefficient.

A key assumption underling this event study method is the hypothesis that prices of the stock market immediately and fully incorporate all the available information i.e. market efficiency hypothesis. Resultantly, the announcement of a Merger or an Acquisition deal leads to a rapid adjustment of the share prices that are related to this event. In order to assess the significance of the adjustment of the share prices, market return model is used.

$$
R_{i t}=\propto_{i}+\beta_{i} R_{m t}+\varepsilon_{i t}
$$

This equation explains the linear relationship between the expected return of the security and the market portfolio.

$R_{i t}$ depicts the actual return of the stock ' $\mathrm{i}$ ' at the time ' $\mathrm{t}$ ',

$\alpha_{i}$ and $\beta_{i}$ depict the coefficients in the model,

$R_{m i t}$ is the market return portfolio 'm' at time ' $\mathrm{t}$ ',

$s_{i t}$ represents the statistical error i.e zero mean distribution term that has an expected value 
$\mathrm{E}\left(\varepsilon_{i t}\right)=0$, constant variance $\operatorname{Var}\left(\varepsilon_{i t}\right)=\sigma_{e i}^{2}$

The differences in the actual returns of the acquirers and targets relative to the predicted return would be calculated over a specific period of time before and after the announcement of the merger. This would help in analyzing whether the merger announcement causes the return of the firm's security to perform differently as compared to the situation without merger announcement.

The holding period return for the acquirers, target firms, R, and for the market, $\boldsymbol{R}_{m}$ was calculated using the following formula:

$$
\mathrm{R}=\left(P_{t+1}-P_{t}\right) / P_{t}
$$

Where $P_{t+1}$ represents the closing price of the current day and $P_{t}$ depicts the closing price of the previous day.

$$
\boldsymbol{R}_{m}=\left(\boldsymbol{P}_{m_{t+1}}-\boldsymbol{P}_{t}\right) / \vec{P} m_{t}
$$

Where $\boldsymbol{P} m_{\varepsilon+1}$ is the market closing price of the current day and $\boldsymbol{P} m_{z}$ is the market closing price of the previous day.

\section{Calculation of Abnormal Returns}

For a given stock, the abnormal return in each of the trading days around the announcement time is defined as a residual.

The abnormal returns on the securities $i$ in the period $t$ is as follows:

$$
A R_{i t}=R_{i t}-\hat{\alpha}-\hat{\beta} R_{m t}
$$

Where $\hat{\alpha}$ and $\hat{\beta}$ are the coefficients estimated by the market model. Table 7 shows the values of Alphas and Betas for all the companies. From the table, we can see that most of those firms have positive Beta values which show that their returns are positively correlated to market index. On the other hand, negative values of Beta represents that returns of those firms are negatively correlated to market returns. $R_{i t}$ represents the actual return for each firm.

In the derivation of the abnormal returns, researchers tend to separate the pre-merger period from the post-merger period in order to calculate the parameters of the market model. Therefore, these parameters are used in the abnormal return calculation process for the time period that is under consideration. 
Calculation of CAR

Average abnormal returns were calculated from the time period -30 to +30 days by taking an average of all abnormal returns across all acquiring or target companies, respectively:

Avg_AR= sum of the abnormal returns/number of companies (18)

Cumulative abnormal return (CAR) was estimated by adding average abnormal return (Avg_AR) from each day from -30 to $t$ days.

t-Test

A t-test was performed to show that the abnormal return values statistically differ from zero. Null hypothesis states that abnormal return for the specified event window is equivalent to zero. McKinlay (1997) mentioned that t-test is referred to as the standardized value of CAR (cumulative abnormal return).

$H_{0:}[\mu(\mathrm{CAR})] /[\sigma(\mathrm{CAR})]=0$

$H_{1}:[\mu(\mathrm{CAR})] /[\sigma(\mathrm{CAR})] \neq 0$

In other words, the Hypotheses that is tested is as follows:

$H_{0}$ : Banking mergers and acquisitions do not have a positive or negative effect on value of banks

$H_{1}$ : Banking mergers and acquisitions do have a positive or negative effect on value of banks

The implication of null hypothesis is that the event has no significant effect on the distribution of the stock returns. If the null hypothesis is not accepted, it can be concluded that the acquisition announcement produced new information and on the basis of market perceptions, the acquisition created or destroyed the value to the firm.

\subsection{Empirical Results}

The Cumulative Average Return, shown in Graph 37 and Average Abnormal Returns, shown in Graph 39 display the fluctuations in return on equities of banks. Series 1 represents the returns of Acquirers and Series 2 represents the returns for the target banks. These graphs depict the relationship of Average AR and CAR to time, specifically the day 0 i.e. announcement date. Table 8 provides the summary of calculated values of AAR and CAR of acquirers and target banks.

By looking at Graph 37, it is evident that merger announcement had an impact on the stock price for a very short time on the target banks, being above 0 until about day 4 and then decreasing with time. On the contrary, it is obvious that announcement of merger had a significant impact on the share prices of acquirers, following an upward trend consistently with 


\section{Mll Macrothink}

a fall in share prices at around day 16 but still above 0 yielding positive returns. It shows that market was optimistic in terms of acquirers. Therefore, this information does give evidence that it could be possible for the acquirers to outperform the market with the merger announcement. Some signs of leakage of information can also be seen as the price begins to rise -1 day before the merger announcement in the case of target banks and prices begin to increase -14 days before the merger announcement for the acquirers. There is a significant fall in share prices after the merger announcement of the target banks that might be because of the economic environment i.e. financial crisis. This also implies that market was getting more pessimistic.

As shown in Graph 38, the CAR values of acquirer banks show positive upward trend during the time period $(-5$ to +5$)$ that surrounds the announcement date. In the case of target banks, the analysis of CAR during the time period -5 to +5 tends to reveal that the negative abnormal movement in the pre-merger time period is accompanied by positive upward trend of abnormal returns in the period of post merger announcement. A steep downward movement can be observed for cumulative abnormal returns in the post merger time period. The upward trend can be seen one day before the merger announcement and then the gain in share prices slips drastically downwards. The results of this research show that earnings announcements do convey useful information for the creation of value for the banks. The CAR graphs show that to some extent, market gradually learns about the merger announcement. Upward trend observed one day before the merger announcement shows signs of leakage of information. This observation contradicts the general belief that target banks involved in merger activities gain more wealth.

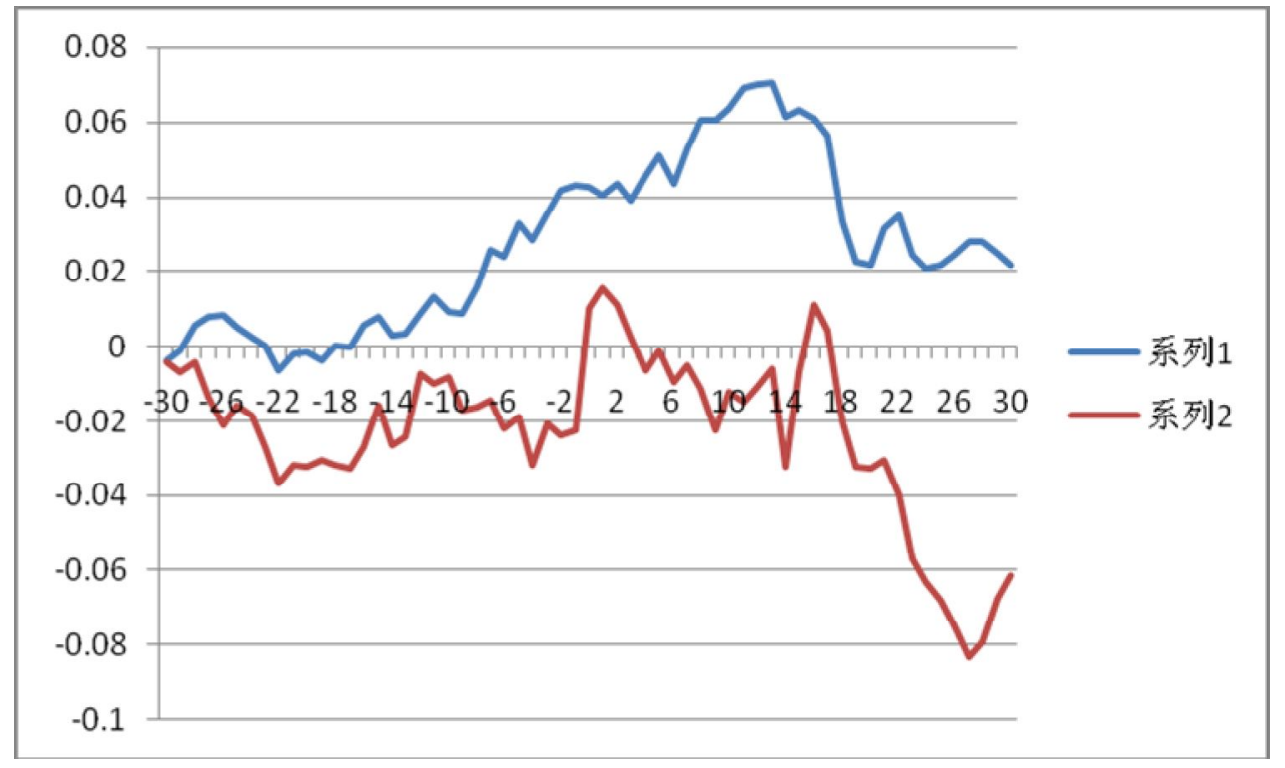

Graph 37 


\section{Graph 38}

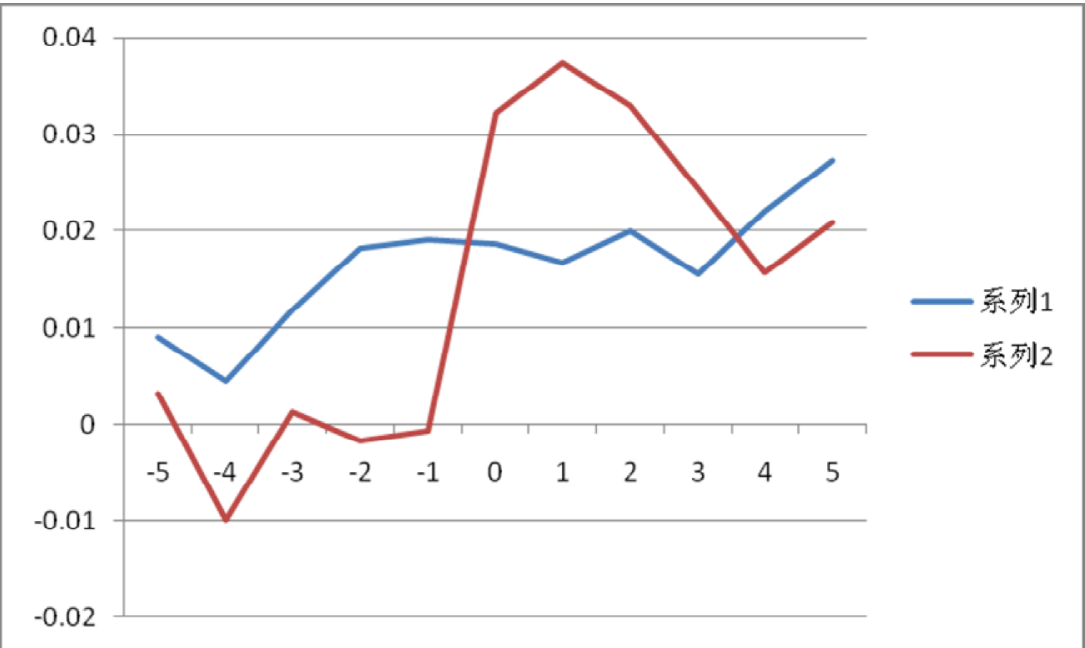

The values of abnormal returns to acquirers and target banks obtained show irregular trends throughout the time period. i.e. volatile (Graph 39). Closer look can be observed from the Graph 40 that shows that from -1 day to +2 day, the average abnormal return has been positive for the target banks. This event study documents an AAR of $0.099 \%$ on day before merger annoucement and $3.2894 \%$ on the announcement date for the target banks. The maximum average AR for the target banks during the time period -5 to +5 was observed on day 0 $(3.2894 \%)$. The analysis of the acquirers from the time period -5 to +5 reveals that there were also negative and positive returns in the window time period. The average AR was $-0.198 \%$ on -1 day and $-0.045 \%$ on day 0 for the acquirers. On the +3 day after the announcement, the average AR was $-0.439 \%$ for the acquirers. If market is efficient, abnormal returns should be back to 0 soon after the merger announcement. Hence, it can be concluded that stock market reacted negatively to the announcement of merger with respect to acquirers. Shareholders of the target banks gain on the day of announcement. For target banks, market is efficient as the share prices rise on the day of announcement and the following day, the abnormal returns return back to the normal. Increased volatility trend has been followed by the share prices of the target banks.

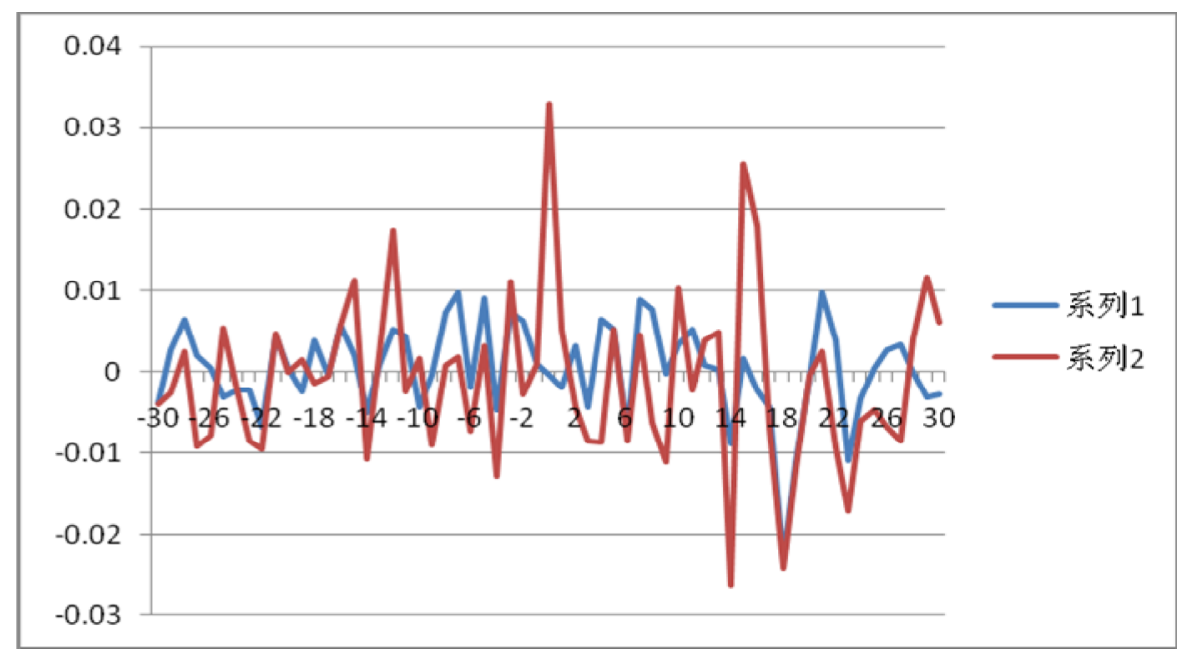

Graph 39 


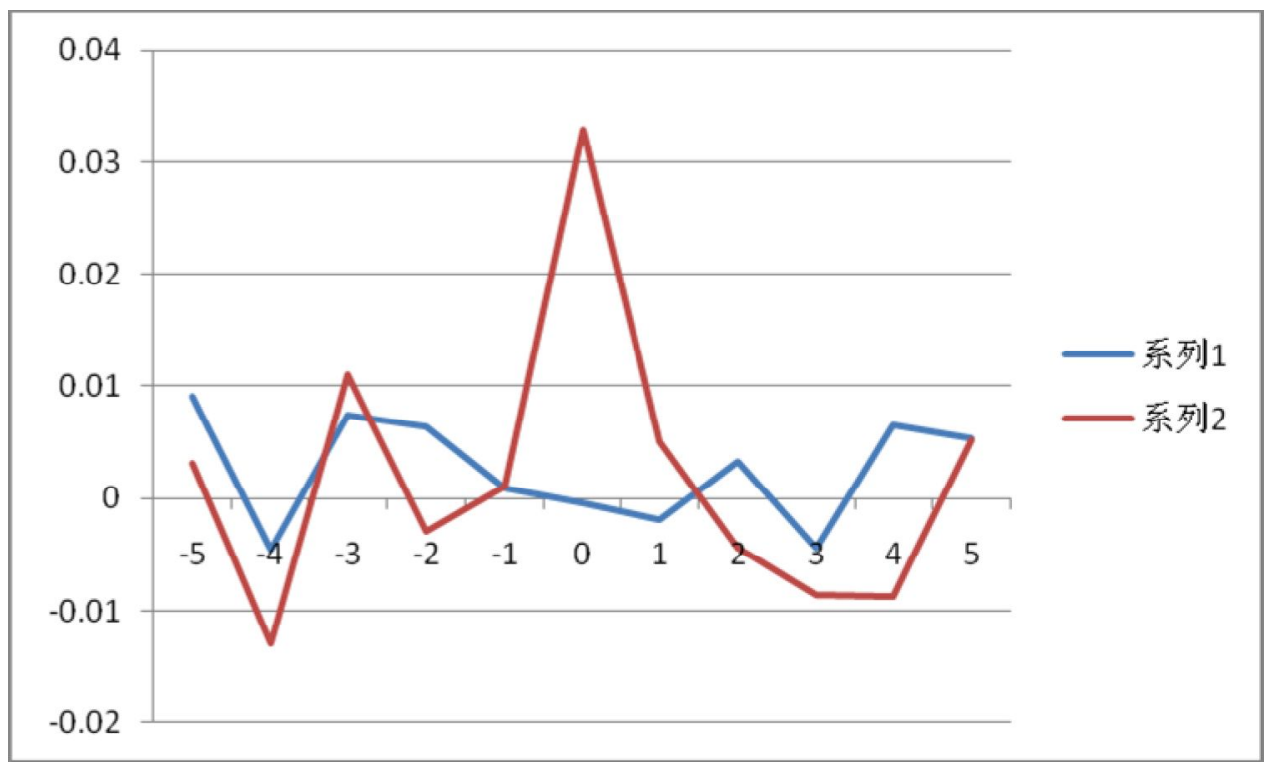

\section{Graph 40}

If statistical tests illustrate that absolute value of t-statistics is equal or higher to the critical $\mathrm{t}$ value (1.96) in both cases i.e. acquirers and target banks, then hypothesis $H_{0}$ will not be accepted implying that AAR or CAR are statistically significant. As shown in Table 9, acquirer and target banks engaged in mergers generated CAR values that are not statistically significant at $5 \%$ for the period $(-30,+30)$. In other words, we can say that there were no cumulative abnormal returns during 2 months for both acquirers and targets. On the other hand, the returns are significant for some time periods $(-30, \mathrm{t})$ i.e. $\mathrm{t}=5,7,8,9$ etc. CAR values are statistically significant at $5 \%$ level for periods $(-5,+5)$. However, acquirers do not earn abnormal returns from the time period $(-1,+1)$ and also on the announcement date $(-1,0)$ leading to the acceptance of $H_{0}$. This implies that any gains of shareholders of acquirers were short lived. Findings also indicate the mergers generate CAR for target banks implying statistical significance at the $5 \%$ level in periods $(0,+1)$ leading to the rejection of $H_{0}$. This indicates that targets earn abnormal returns on merger announcement. Whereas for the time period $(-30,+30)$ and $(-5,+5)$ results are statistically not significant which shows that there were no abnormal returns over a specified time period. This implies that share holders of target banks earned abnormal returns on the day of merger announcement. Table 10 provides the $t$ values of AAR for both acquirers and target banks. It can be seen from the table that significant abnormal returns are observed for $\mathrm{t}=-7,-5,7,14,19$, and 23 in the case of acquirers. However, the acquirers did not earn abnormal returns when $\mathrm{t}=-4,-3,-2,1,2$, etc and also on the announcement date. In the case of target banks, it was observed that abnormal returns were only earned when $t=-12,0,15$ and 16 around on the merger announcements. 


\begin{tabular}{|c|c|c|c|c|c|c|}
\hline \multirow{3}{*}{$\begin{array}{l}\text { Event } \\
-30 \\
\end{array}$} & \multicolumn{2}{|c|}{ Acquirers } & & \multicolumn{2}{|c|}{ Target } & \\
\hline & \multirow{2}{*}{$\begin{array}{c}\text { AAR } \\
-0.00388\end{array}$} & \multicolumn{2}{|c|}{ CAR } & \multirow{2}{*}{$\begin{array}{c}\mathbf{A A R} \\
-0.00402\end{array}$} & \multicolumn{2}{|c|}{ CAR } \\
\hline & & -0.00388 & & & -0.00402 & \\
\hline-29 & 0.002757 & -0.00112 & & -0.00265 & -0.00667 & \\
\hline-28 & 0.006502 & 0.005383 & & 0.002483 & -0.00419 & \\
\hline-27 & 0.002067 & 0.00745 & & -0.00918 & -0.01337 & \\
\hline-26 & 0.000514 & 0.007964 & & -0.0078 & -0.02116 & \\
\hline-25 & -0.00318 & 0.004782 & & 0.005295 & -0.01587 & \\
\hline-24 & -0.00225 & 0.002536 & & -0.00231 & -0.01818 & \\
\hline-23 & -0.00233 & 0.00021 & & -0.00858 & -0.02676 & \\
\hline-22 & -0.00682 & -0.00661 & & -0.00967 & -0.03643 & \\
\hline-21 & 0.004536 & -0.00208 & & 0.004631 & -0.0318 & \\
\hline-20 & 0.000512 & -0.00156 & & -0.00013 & -0.03192 & \\
\hline-19 & -0.00236 & -0.00393 & & 0.001444 & -0.03048 & \\
\hline-18 & 0.003966 & $3.73 \mathrm{E}-05$ & & -0.00143 & -0.03191 & \\
\hline-17 & -0.00034 & -0.0003 & & -0.00071 & -0.03262 & \\
\hline-16 & 0.005816 & 0.005518 & & 0.005704 & -0.02692 & \\
\hline-15 & 0.002022 & 0.00754 & & 0.011253 & -0.01566 & \\
\hline-14 & -0.00497 & 0.002566 & & -0.01074 & -0.02641 & \\
\hline-13 & 0.000863 & 0.003429 & & 0.002143 & -0.02426 & \\
\hline-12 & 0.005252 & 0.008681 & & 0.01716 & -0.0071 & \\
\hline-11 & 0.004457 & 0.013138 & & -0.00255 & -0.00965 & \\
\hline-10 & -0.00426 & 0.008873 & & 0.001603 & -0.00805 & \\
\hline-9 & -0.00045 & 0.008426 & & -0.00899 & -0.01704 & \\
\hline-8 & 0.007378 & 0.015804 & & 0.000782 & -0.01625 & \\
\hline-7 & 0.0098 & 0.025604 & & 0.001732 & -0.01452 & \\
\hline-6 & -0.00197 & 0.02363 & & -0.00732 & -0.02184 & \\
\hline-5 & 0.009052 & 0.032683 & 0.009052 & 0.003081 & -0.01876 & 0.003081 \\
\hline-4 & -0.0046 & 0.028079 & 0.004449 & -0.01292 & -0.03168 & -0.00984 \\
\hline-3 & 0.007392 & 0.035471 & 0.011841 & 0.011098 & -0.02058 & 0.001262 \\
\hline-2 & 0.006326 & 0.041797 & 0.018166 & -0.00292 & -0.0235 & -0.00166 \\
\hline-1 & 0.000921 & 0.042718 & 0.019088 & 0.00099 & -0.02251 & -0.00067 \\
\hline 0 & -0.00045 & 0.042267 & 0.018637 & 0.032894 & 0.010384 & 0.032226 \\
\hline 1 & -0.00198 & 0.040285 & 0.016654 & 0.005129 & 0.015513 & 0.037355 \\
\hline 2 & 0.003229 & 0.043513 & 0.019883 & -0.00439 & 0.011119 & 0.03296 \\
\hline 3 & -0.00439 & 0.039125 & 0.015495 & -0.00854 & 0.002576 & 0.024418 \\
\hline 4 & 0.006543 & 0.045668 & 0.022037 & -0.0087 & -0.00613 & 0.015716 \\
\hline 5 & 0.005296 & 0.050964 & 0.027334 & 0.00517 & -0.00096 & 0.020886 \\
\hline 6 & -0.00743 & 0.043534 & & -0.00848 & -0.00944 & \\
\hline 7 & 0.009001 & 0.052535 & & 0.004498 & -0.00494 & \\
\hline 8 & 0.007783 & 0.060318 & & -0.00633 & -0.01127 & \\
\hline 9 & -0.00012 & 0.060195 & & -0.01119 & -0.02246 & \\
\hline 10 & 0.003424 & 0.063619 & & 0.010255 & -0.01221 & \\
\hline 11 & 0.005384 & 0.069003 & & -0.00245 & -0.01466 & \\
\hline
\end{tabular}




\begin{tabular}{|r|r|r|r|l|r|r|r|l|}
\hline 12 & 0.000808 & 0.069811 & & & 0.003766 & -0.01089 & & \\
\hline 13 & 0.000349 & 0.07016 & & & 0.004844 & -0.00605 & & \\
\hline 14 & -0.0089 & 0.061265 & & & -0.02627 & -0.03232 & & \\
\hline 15 & 0.001639 & 0.062904 & & & 0.025528 & -0.00679 & & \\
\hline 16 & -0.00222 & 0.06068 & & 0.017962 & 0.011173 & \\
\hline 17 & -0.00428 & 0.056397 & & -0.00693 & 0.004243 & \\
\hline 18 & -0.02313 & 0.033263 & & -0.02428 & -0.02004 & \\
\hline 19 & -0.01108 & 0.022188 & & -0.01201 & -0.03204 & \\
\hline 20 & -0.00077 & 0.021422 & & -0.00053 & -0.03257 & \\
\hline 21 & 0.00976 & 0.031182 & & 0.002412 & -0.03016 & \\
\hline 22 & 0.003866 & 0.035048 & & -0.00936 & -0.03952 & \\
\hline 23 & -0.01094 & 0.024111 & & -0.01719 & -0.05671 & \\
\hline 24 & -0.00329 & 0.020826 & & & -0.0061 & -0.06281 & \\
\hline 25 & 0.000557 & 0.021383 & & & -0.0048 & -0.06761 & \\
\hline 26 & 0.002771 & 0.024154 & & -0.00677 & -0.07438 & \\
\hline 27 & 0.003506 & 0.02766 & & & -0.00852 & -0.0829 & \\
\hline 28 & $-3.5 \mathrm{E}-05$ & 0.027625 & & & 0.004019 & -0.07888 & \\
\hline 29 & -0.00316 & 0.024462 & & & 0.011516 & -0.06736 & \\
\hline 30 & -0.00278 & 0.021686 & & & 0.006069 & -0.06129 & \\
\hline
\end{tabular}

Table 8 Notes: AAR average abnormal return

CAR cumulative abnormal return

Summary of $\mathrm{t}$ statistics

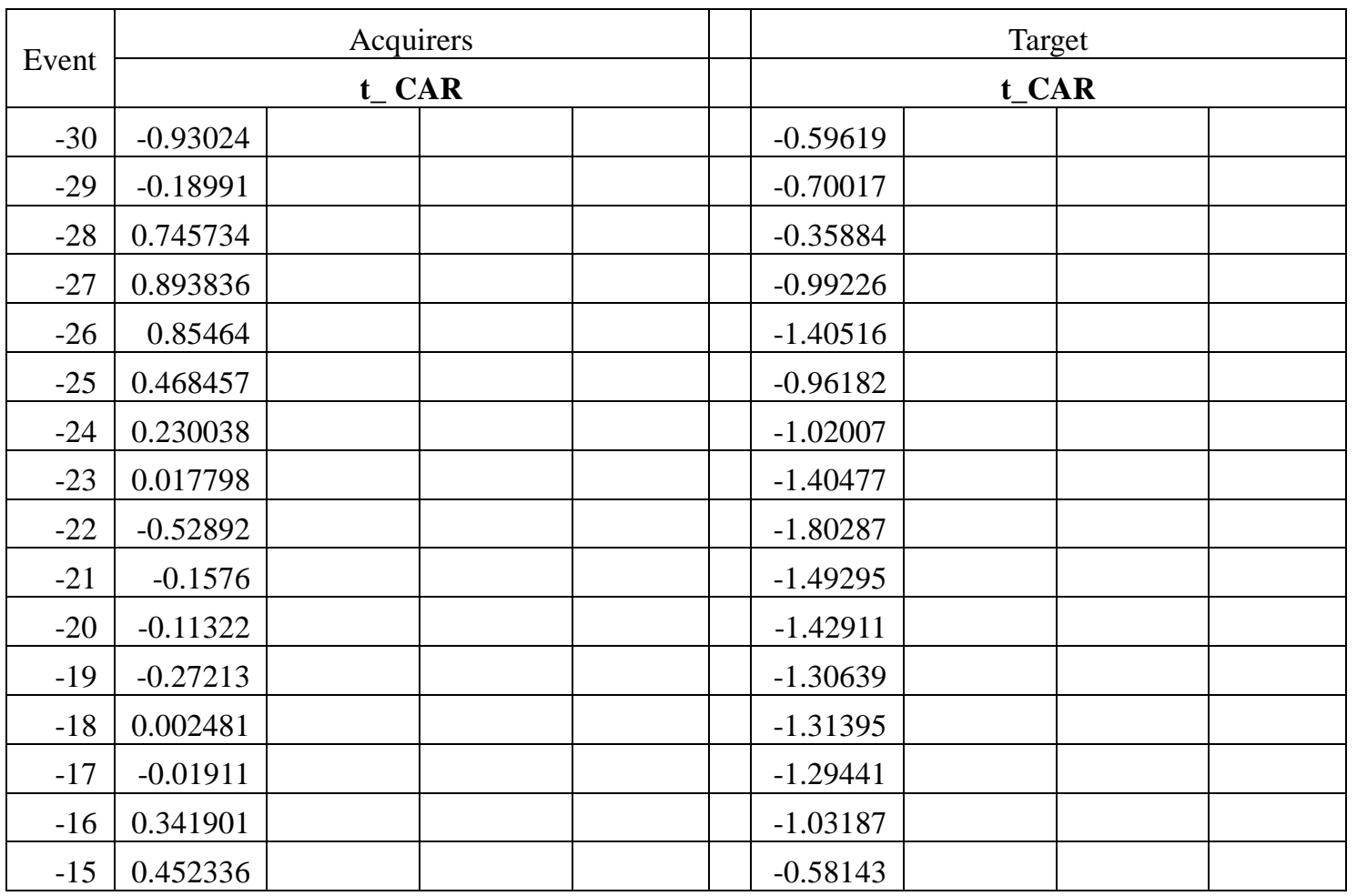




\begin{tabular}{|c|c|c|c|c|c|c|c|c|}
\hline-14 & 0.149359 & & & & -0.95083 & & & \\
\hline-13 & 0.193933 & & & & -0.84906 & & & \\
\hline-12 & 0.477881 & & & & -0.24194 & & & \\
\hline-11 & 0.704927 & & & & -0.3204 & & & \\
\hline-10 & 0.464616 & & & & -0.26075 & & & \\
\hline-9 & 0.431074 & & & & -0.53929 & & & \\
\hline-8 & 0.790731 & & & & -0.50321 & & & \\
\hline-7 & 1.254111 & & & & -0.44014 & & & \\
\hline-6 & 1.13404 & & & & -0.64856 & & & \\
\hline-5 & 1.538011 & 2.172148 & & & -0.54624 & 0.457505 & & \\
\hline-4 & 1.296664 & 0.754811 & & & -0.90512 & -1.03263 & & \\
\hline-3 & 1.608502 & 1.640363 & & & -0.57743 & 0.108155 & & \\
\hline-2 & 1.862387 & 2.17953 & & & -0.64788 & \begin{tabular}{|l|}
-0.12307 \\
\end{tabular} & & \\
\hline-1 & 1.871451 & 2.048309 & 0.221098 & & -0.61016 & -0.04437 & 0.146936 & \\
\hline 0 & 1.821584 & 1.825666 & 0.079824 & 0.10821 & 0.276893 & 1.953254 & 3.557184 & 4.88368 \\
\hline 1 & 1.708802 & 1.510439 & -0.20947 & 0.41289 & 0.407153 & 2.096193 & 3.344098 & 3.99177 \\
\hline 2 & 1.817578 & 1.6868 & & & 0.287361 & 1.730137 & & \\
\hline 3 & 1.610073 & 1.239352 & & & 0.065602 & 1.20844 & & \\
\hline 4 & 1.852267 & 1.672199 & & & -0.15373 & 0.73786 & & \\
\hline 5 & 2.038173 & 1.977564 & & & -0.02366 & 0.934945 & & \\
\hline 6 & 1.717354 & & & & -0.23031 & & & \\
\hline 7 & 2.044961 & & & & -0.11892 & & & \\
\hline 8 & 2.317635 & & & & -0.26794 & & & \\
\hline 9 & 2.283809 & & & & -0.52736 & & & \\
\hline 10 & 2.384081 & & & & -0.2831 & & & \\
\hline 11 & 2.554885 & & & & -0.33576 & & & \\
\hline 12 & 2.554573 & & & & -0.24656 & & & \\
\hline 13 & 2.538019 & & & & -0.13533 & & & \\
\hline 14 & 2.191463 & & & & -0.71524 & & & \\
\hline 15 & 2.225487 & & & & -0.14861 & & & \\
\hline 16 & 2.123843 & & & & 0.241963 & & & \\
\hline 17 & 1.953275 & & & & 0.090934 & & & \\
\hline 18 & 1.140227 & & & & -0.42501 & & & \\
\hline 19 & 0.752927 & & & & -0.67281 & & & \\
\hline 20 & 0.719775 & & & & -0.67713 & & & \\
\hline 21 & 1.037607 & & & & -0.62093 & & & \\
\hline 22 & 1.155185 & & & & -0.80595 & & & \\
\hline 23 & 0.787311 & & & & -1.14578 & & & \\
\hline 24 & 0.673821 & & & & -1.25746 & & & \\
\hline 25 & 0.685648 & & & & -1.34132 & & & \\
\hline 26 & 0.767676 & & & & -1.46262 & & & \\
\hline 27 & 0.871497 & & & & -1.61607 & & & \\
\hline 28 & 0.862993 & & & & -1.52464 & & & \\
\hline 29 & 0.757774 & & & & -1.29115 & & & \\
\hline
\end{tabular}


Table 9

Summary of $\mathrm{t}$ statistics

\begin{tabular}{|c|c|c|c|c|c|}
\hline \multirow{2}{*}{ Event } & Acquirers & Target & \multirow{2}{*}{ Event } & Acquirers & Target \\
\hline & t_AAR & t_AAR & & t_AAAR & t_AAR \\
\hline-30 & -0.93024 & -0.59619 & 0 & -0.10821 & 4.883682 \\
\hline-29 & 0.661667 & -0.394 & 1 & -0.4757 & 0.761529 \\
\hline-28 & 1.560225 & 0.368664 & 2 & 0.774745 & -0.65244 \\
\hline-27 & 0.496022 & -1.36301 & 3 & -1.05294 & -1.26825 \\
\hline-26 & 0.123361 & -1.15751 & 4 & 1.569903 & -1.292 \\
\hline-25 & -0.76355 & 0.78607 & 5 & 1.270878 & 0.767543 \\
\hline-24 & -0.53886 & -0.3429 & 6 & -1.78278 & -1.25898 \\
\hline-23 & -0.55828 & -1.27441 & 7 & 2.15973 & 0.667874 \\
\hline-22 & -1.63709 & -1.43533 & 8 & 1.867636 & -0.94022 \\
\hline-21 & 1.088377 & 0.687496 & 9 & -0.02955 & -1.66208 \\
\hline-20 & 0.122878 & -0.01872 & 10 & 0.821493 & 1.5226 \\
\hline-19 & -0.5672 & 0.214346 & 11 & 1.291979 & -0.36324 \\
\hline-18 & 0.951637 & -0.21204 & 12 & 0.19391 & 0.559176 \\
\hline-17 & -0.08045 & -0.10573 & 13 & 0.083858 & 0.719128 \\
\hline-16 & 1.395682 & 0.846836 & 14 & -2.13454 & -3.90031 \\
\hline-15 & 0.485169 & 1.67069 & 15 & 0.393209 & 3.790064 \\
\hline-14 & -1.19352 & -1.59466 & 16 & -0.53365 & 2.66674 \\
\hline-13 & 0.206967 & 0.318114 & 17 & -1.02765 & -1.02881 \\
\hline-12 & 1.260245 & 2.547681 & 18 & -5.5511 & -3.60504 \\
\hline-11 & 1.069498 & -0.37828 & 19 & -2.65759 & -1.78247 \\
\hline-10 & -1.02339 & 0.237961 & 20 & -0.18378 & -0.07816 \\
\hline-9 & -0.10722 & -1.33458 & 21 & 2.342068 & 0.358064 \\
\hline-8 & 1.770295 & 0.116172 & 22 & 0.927586 & -1.38977 \\
\hline-7 & 2.351652 & 0.257075 & 23 & -2.62435 & -2.55236 \\
\hline-6 & -0.47366 & -1.08656 & 24 & -0.78834 & -0.90585 \\
\hline-5 & 2.172148 & 0.457505 & 25 & 0.133729 & -0.71195 \\
\hline-4 & -1.10468 & -1.91786 & 26 & 0.664904 & -1.00503 \\
\hline-3 & 1.773728 & 1.647686 & 27 & 0.841303 & -1.26509 \\
\hline-2 & 1.517869 & -0.43347 & 28 & -0.00835 & 0.596663 \\
\hline-1 & 0.221098 & 0.146936 & 29 & -0.75908 & 1.709741 \\
\hline & & & 30 & -0.66609 & 0.901126 \\
\hline
\end{tabular}

Table 10

\section{Conclusion}

A merger or acquisition is assumed to create value if the returns on the shares of the acquirers and targets increase on the announcement of the merger. This research had one primary objective. We had to examine the effects of a merger announcement of banks on stock values. 


\section{Mll Macrothink}

Business and Economic Research

ISSN 2162-4860

2013, Vol. 3, No. 1

Eighteen acquiring banks and 18 target banks were used in the sample for the study of price reactions of stocks. Returns on stocks of banks were compared to the market returns i.e. FTSE100 index. The findings reveal that there is definitely action in the prices of stocks around Day 0, but the analysis also shows that the merger may not be significant in determination of the reason for the particular behaviour.

The results of this study explain that mergers or acquisitions in the banking sector tend to be positive net present value activities for a short period for the acquirers. Moreover, it elaborates that acquirer banks confirm the point that merger announcements are consistent with the maximization of value. Value creation, which was short lived for acquirers, depicts the confidence of the investors in the ability of the acquirers to turnaround the inefficient target banks. It also shows that target banks experienced significant abnormal returns on the day of merger announcement. The study also found out that the performance of the target banks did not improve after mergers announcement. Perhaps the real economic gains could be examined over a longer time period. By analyzing the available information, this study has analyzed the reaction of stock market to the announcement of mergers or acquisitions and identified that it creates positive gains for the acquirers only for two weeks i.e. CAR $(-5,+5)$ is statistically greater than 0 where as CAR during two months $(-30,+30)$ were equal to 0 . We looked at a very brief time period to evaluate the value creation for the banks; therefore it is impossible to say if acquirers will benefit from the actual merger in the longer term.

\section{References}

Agarwal, S. (2007, September). Mergers and Acquisition in Tea Industry: A case study. Retrieved July 2011,

http://edissertations.nottingham.ac.uk/1579/1/Mergers_and_acquisitions_in_tea_industry.pdf

Ayadi, R. and Pujals, G. (2005). Banking Mergers and Acquisitions in EU: Overview, Assessment and Prospects. Retrieved August 2011.

http://www.suerf.org/download/studies/study20053.pdf

Berger, M. (2011, February 10). Famous Stock and Securities Market Mergers and Acquisitions. News in Brief, Retrieved July 2011.

http://www.publicradio.org/columns/marketplace/business-news-briefs/2011/02/famous_stoc k_market_mergers_and_acquisitions.html

Berger,A. N, Bonime, S. D, Goldberg, L. G, \& White, J. L. (2004, October). The Dynamics of Market Entry: The effects of Mergers and Acquisitions on Entry in Banking Industry. The Journal of Business, Retrieved June 2011. http://www.jstor.org/stable/10.1086/422439

Berkovitch, E and Narayanan, M. P. (1993, September). Motives for Takeovers: An Empirical Investigation. Jstor. Retrieved June 2011, http://www.jstor.org/stable/2331418

Bild, M. Guest, P. Cosh, A. \& Runsten, M. (2002, December). Do takeovers create value? . Retrieved July 2011, http://www.cbr.cam.ac.uk/pdf/WP252.pdf 
Billet, M. T, King,T. H. D, \& Mauer, D. C. (2004, February). Bondholder Wealth Effects in Mergers and Acquisitions: New Evidence from the 1980s and 1990s. The Journal of Finance. Retrieved June 2011. http://www.jstor.org/stable/3694891

Blumenthal, J. (2008, October 14). Santander to buy Sovereign Bancorp for \$1.9B. Retrieved July 2011. http://www.bizjournals.com/philadelphia/stories/2008/10/13/daily13.html

Brown, S. and Warner, J. (1985). Using Daily Stock Returns. Journal of Financial Economics , 3-31. http://dx.doi.org/10.1016/0304-405X(85)90042-X

Caves, R. E. (1987). Effects of Mergers and Acquisitions on the Economy: An Industrial Organization Perspective. Retrieved July 2011.

http://www.bos.frb.org/economic/conf/conf31/conf31f.pdf

DePamphilis, D. M. (2009). Case Study: Lehman Brothers Files for Chapter 11. Retrieved July 2011.

http://knol.google.com/k/case-study-lehman-brothers-files-for-chapter-11 ?collectionId=2y716 718la2ns.28\#

Elazar Berkovitch, M. P. (1993, September). Motives for Takeovers: An Empirical Investigation. Retrieved June 2011. http://www.jstor.org/stable/2331418

Espinoza, J. (2008, October 13). Santander Swoops On Sovereign. Retrieved from http://www.forbes.com/2008/10/13/santander-sovereign-closer-markets-equity-cx_je_lal_101 3markets35.html

Focarelli,D. and Panetta, F. (2003, September). Are Mergers Beneficial to Consumers? Evidence from the Market for Bank Deposits. Retrieved June 2011.

http://www.jstor.org/stable/pdfplus/3132283

Focarello, D, Panetta, F, and Salleo, C. (2002, November). Why do Banks merge? Retrieved June 2011. http://www.jstor.org/stable/3270727

Hadlock, Charles J., Joel E Houston, \& Michael D. Ryngaert (1999, April). The Role of Managerial Incentives in Bank Acquisitions Retrieved June 2011; Journal of Banking and Finance, 221-249

Halpern, P. (1983). Corporate Acquisitions: A theory of Special Cases. A Review od event studies applied to Acquisitions. The Journal of Finance, 297-317. http://dx.doi.org/10.2307/2327962

Harford, J. (2005). What drives merger waves? Retrieved June 2011, Journal of Financial Economics.

http://faculty.bschool.washington.edu/jarrad/papers/harford-what_drives_merger_waves.pdf

Koch, A. (2009). Merger of HQ Bank AB completed - all operations conducted under Carnegie. Retrieved July 2011. 
http://www.carnegie.se/en/about/PressIR/Press-Releases/?releaseid=515553

Lambert, R. A, Lanen, W. N. and Larcker, D. F. (1989). Executive Stock Option Plans and Corporate Dividend Policy, Journal of Financial and Quantitative Analysis, 24(4), 409-425.

http://dx.doi.org/10.2307/2330976

Macaskill, A. and Menon, J. (2009, March 9). Lloyds the latest UK bank to be rescued. Retrieved August 2011.

http://www.theage.com.au/business/lloyds-the-latest-uk-bank-to-be-rescued-20090308-8sfd.h tml

McGlasson, L. (2008, October 20). Banco Santander Buys Sovereign Bank for \$1.9 Billion. Retrieved July 2011. http://www.bankinfosecurity.com/articles.php?art_id=1015

Bibliography, MacKinlay, C. (1997). Event Studies in Economics and Finance. Journal of Economic Literature, 13-39.

Minney, T. (2011, February 25). Stock exchange merger trend will end with "three, four" global exchanges. Retrieved July 2011, African Capital Markets News.

http://www.africancapitalmarketsnews.com/921/stock-exchange-merger-trend-will-end-with$\% \mathrm{E} 2 \% 80 \% 9 \mathrm{Cthree-four} \% \mathrm{E} 2 \% 80 \% 9 \mathrm{D}$-global-exchanges/

Mody, A., Moeller,S. B, Schlingemann, F. P, \& Stulz, R. M. (2005, April). Wealth Destruction on a Massive Scale? A study of Acquiring Firm Returns in the Recent Merger Wave. Retrieved June 2011, The Journal of Finance.

http://www.cob.ohio-state.edu/fin/faculty/stulz/publishedpapers/Wealth\%20Destruction_JF.p df

Morris, T. (2004, September). Bank Mergers Under a Changing Regulatory Environment. Retrieved June 2011. http://www.jstor.org/stable/pdfplus/4148819

Mueller, D. C. (1985, May). Mergers and Market Share. Retrieved June 2011.

http://www.jstor.org/stable/1924725

Mukherjreem,T, K, Kiymaz, H and Baker, K. (2004). Merger Motives and Target Valuation: A Survey of Evidence. Retrieved June 2011, from CFOs.

http://www.scribd.com/doc/29279965/Motive

\}Neary, J. P. (2007). Cross-Border Mergers as Intruments of Comparative Advantage. Retrieved June 2011, from Jstor: http://www.jstor.org/stable/pdfplus/4626179

Negishi, A. M. (2001, March ). Cross-Border Mergers and Acquisitions in East Asia: Trends and Implications. Retrieved June 2011, from International Monetary Fund: http://www.imf.org/external/pubs/ft/fandd/2001/03/mody.htm 


\section{Macrothink}

Business and Economic Research ISSN 2162-4860 2013, Vol. 3, No. 1

No Author. (n.d.). Case Studies on Big Bank. Retrieved July 2011, from http://www.download-it.org/free_files/filePages\%20from\%20Case $\% 20$ Studies $\% 20$ on $\% 20 \mathrm{Bi}$ g\%20Bank\%20Mergers\%20in\%20Europe.pdf

No Author. (2008, September 18). Lloyds TSB announces HBOS takeover. Retrieved July 2011, from Business Day.

http://www.businessday.com.au/business/lloyds-tsb-announces-hbos-takeover-20080918-4isy .html

Pautler, P. A. (2003, March 22). Evidence on Mergers and Acquisitions. Retrieved July 2011, http://business.highbeam.com/420683/article-1G1-108150635/evidence-mergers-and-acquisit ions

Peston, R. (2008, September 17). The creation of Lloyds HBOS. Retrieved July 2011, from $\mathrm{BBC}$

News. http://www.bbc.co.uk/blogs/thereporters/robertpeston/2008/09/the_creation_of_lloyds_hbos. html

Rockett, J. (2008, August 1). The Urge to Merge: Trends in Bank Mergers. Retrieved July

Sharma, V. (2009, December 17). Do Bank Mergers create Shareholder Value? Retrieved July 2011. http://www.minneapolisfed.org/mea/contest/2010papers/sharma.pdf

Sherman, A. J, Morin, D. S. and LLP, O. (2011). Mergers and Acquisitions: An Introduction. Retrieved August 2011.

http://www.entrepreneurship.org/en/resource-center/mergers-and-acquisitions-an-introduction .aspx

Thomson Reuters. (n.d.). Retrieved August 2011.

http://www.alacrastore.com/storecontent/Thomson_M\&A/Bank_of_North_America_Miami_ FL_acquires_First_Coml_Bk_of_FL_Boca_Raton-183730020

White, E. N. (1985). The Merger Movement in Banking. The Journal of Economic History, 45(2),285-291. http://dx.doi.org/10.1017/S0022050700033969

\section{Copyright Disclaimer}

Copyright reserved by the author(s).

This article is an open-access article distributed under the terms and conditions of the Creative Commons Attribution license (http://creativecommons.org/licenses/by/3.0/). 